This is the peer reviewed version of the following article:

Alexander Burcat, Elke Goos,

Ideal gas thermochemical properties of silicon containing

inorganic, organic compounds, radicals, and ions,

Int J Chem Kinet. 2018;50:633-650,

which has been published in final form at http://dx.doi.org/10.1002/kin.21188.

This article may be used for non-commercial purposes in accordance with Wiley Terms and Conditions for Self-Archiving. 


\title{
Ideal Gas Thermochemical Properties of Silicon containing Inorganic, Organic Compounds, Radicals and Ions.
}

\author{
Alexander Burcat \\ Faculty of Aerospace Engineering, Technion- Israel Institute of Technology, \\ Haifa 32000, Israel, \\ aer0201@technion.ac.il
}

and

Elke Goos,

Institute of Combustion Technology, Deutsches Zentrum für Luft- und Raumfahrt e.V.

(DLR, German Aerospace Center), Pfaffenwaldring 38, 70569 Stuttgart, Germany. elke.goos@dlr.de

\begin{abstract}
The ideal gas thermochemical properties such as standard heat of formation, entropy and heat capacities of 112 inorganic and 35 organic neutral compounds, radicals and ions containing silicon were calculated using molecular properties obtained with the G3B3 (or G3//B3LYP) method. Among them were linear and cyclic silanes, silenes, hydrocarbonsilanes, fluorine and oxygen containing compounds. Many of their molecular and thermodynamic properties were calculated for the first time and 16 of them had no CAS No.

Additionally the thermochemical properties were presented in the NASA 7-term polynomial format for the temperature range of $200 \mathrm{~K}$ to $6000 \mathrm{~K}$ commonly used in chemical kinetic modeling and simulation programs. The polynomials are available in the supplement to this article free of charge.
\end{abstract}




\section{KEYWORDS}

Thermodynamic data, Thermochemistry, Thermochemical properties, Heat of formation, Entropy, Enthalpy, Heat capacity, NASA format, Quantum chemical calculation, G3B3 composite approach, Silicon hydride, Silanes, Silicon fluoride, Silicon hydrocarbon, Silicon ions, Silicon compounds, Database

\section{INTRODUCTION}

Silicon containing substances are widely used and important for the mankind. For example silicon, a crystalline substance at room temperature, is used intensively in photovoltaic and solar cells, in light-emitting devices and by the electronic industry within semiconductors and integrated circuits and therefore silicon is used nearly in every electronic device such as mobile phones, computers and equipment containing control units. On the other hand the commonly known Silicons are polysiloxanes which are polymers. They are widely used as heat resistant rubber-like plastic compounds, but are not part of this publication.

Silicon has a high affinity to oxygen and therefore different silicon oxides exist in dusts and sands or as minerals. Silanes, the analogues compounds to hydrocarbons, are pyrophoric and used as reducing agents in organic and organometallic chemistry and as precursors to elemental silicon in chemical vapor decomposition processes used in the manufacturing of semiconductors and of solar photovoltaic modules. In chemical vapor deposition processes plasma or electric discharge can decompose silanes into more reactive compounds such as radicals, which react instantaneously with the surface. For etching of metal surfaces halogenated silanes as $\mathrm{SiF}_{4}$ are used.

The thermochemistry of silicon containing substances has received a fair amount of publications which are usually restricted to small inorganic and organic molecules. To the best of our knowledge, ions were investigated before only for the inorganic species.

It was noted that due to experimental problems the calorimetric values reported before 1970 are erroneous [1].

The first publication including thermochemical tables of diatomic silicon hydride, deuteride and tritide was to our knowledge the NBS monograph No. 20 (1961) [2] by Haar, Friedman and Beckett, which did not include enthalpies of formation values. A few Silicon gaseous compounds were published in the JANAF tables during the 1960's and 1970's [3]. Glushko, Gurvich et al. (1970) [4] published a few tritide containing Silicon inorganic compounds. Gurvich published some Silicon compounds in his different editions (1989- 
1996) [5]; Walsh recorded the thermochemistry of silicon containing substances in the second part of volume 1, which was edited by Rappoport (1989) [1]. In the same volume $\mathrm{H}$. Schmidt discusses the structure of silicon cations and anions, but does not include thermochemical data. Rappoport and Apeloig updated the former title as volume 2 in three parts (1998) [6]. The thermochemical chapter of Walsh (now chapter 4) was updated by Becerra [6]. Wiberg and coworkers (1995) [7] included a few silicon compounds in their comparison of ab-initio methods; Boo and Armentrout (1987) [8] calculated monosiliconhydrides and deuterides; Broadbelt and coworkers (2004) [9] calculated 135 Silicon-Hydrogen compounds; Ho and Melius (1990) [10] calculated some fluorosilane compounds. Allendorf, Melius et al. (1995) [12] report calculations on Si-O-H compounds, and some of Melius's data from his internal Sandia database were incorporated in the Chemkin thermochemical database (1982) [13]. Lyman and Noda (2001) [14] calculated $\mathrm{SiF}_{4}$ and $\mathrm{Si}_{2} \mathrm{~F}_{6}$ compounds, and also Lias et al. (1988) [15] estimated some silicon compounds and cations. Katzer et al. (1997) [31] calculated thermochemical data for more than 140 silicon hydride compounds containing up to five silicon atoms using an validated empirically corrected ab initio methodology for the standard state at $298.15 \mathrm{~K}$. Feller and Dixon (1999) [43] calculated ab initio enthalpies of formation for $\mathrm{SiH}$ to $\mathrm{SiH}_{4}, \mathrm{Si}_{2} \mathrm{H}_{4}$ and $\mathrm{SiF}$ to $\mathrm{SiF}_{4}$. They reported $\Delta_{\mathrm{f}} H^{\circ}(0 \mathrm{~K})$ values, which are common in quantum chemical studies, instead of the reference value of $298.15 \mathrm{~K}$, which is commonly used by engineers. We provide calculated heat of formation values for both temperatures to make the comparison of data with different reference temperatures easier. Takhistov and Golovin (2006) [48] did not calculate any new data, but analyzed the existing literature for many elements including silicon and decided by comparison which is the best value. Sukkaew et al. (2014) [16] calculated some Si-C-H compounds. And finally M.C. Lin and coworkers published in 2013-2017 [60-64] articles about $\mathrm{SiH}_{\mathrm{x}}$ and $\mathrm{Si}_{2} \mathrm{H}_{\mathrm{y}}$ family including some cations.

In 2007 Karton and Martin [52] published a revised value of the heat of formation of the gaseous Silicon atom i.e. $\Delta_{\mathrm{f}} H^{\circ}(298 \mathrm{~K})=452.7 \pm 0.8 \mathrm{~kJ} \mathrm{~mol}^{-1}$ calculated by their novel $\mathrm{W} 4$ ab-initio method. The value used in this article is $\Delta_{\mathrm{f}} H^{\circ}(298 \mathrm{~K})=450 \pm 0.8 \mathrm{~kJ} \mathrm{~mol}^{-1}$ [19]. Therefore the error bar was enlarged for molecules containing more than three Silicon atoms.

The Group Additivity (GA) contributions for the heat of formation of silicon compounds were discussed and published with reservations by Walsh (1989) [1], slightly extended by Becerra and Walsh [6], but they do not include GA coefficients for entropy $S$ and heat capacities $C_{p}(\mathrm{~T})$. 
Swihart and Girshick (1999) [32] used the silicon hydrides ab initio data of Katzer et al. (1997) [31] to calculate reliable thermochemical group additivity values for temperatures up to $1500 \mathrm{~K}$.

The MIT RMG thermochemical database has included lately (2016) [17] a limited number of silicon compounds, but most of their silicon containing data are at the moment out of context due to wrong connections to group additivity values of carbon compounds instead of silicon group data. On the other hand, West and coworkers (2016) [18] provide in their paper supplement much more reliable thermochemical data of silicon hydrides, which can be used with RMG and other estimating programs.

The aim of this article is to provide ideal gas thermochemical data for inorganic, and organic silicon containing species and their ions calculated by the G3//B3LYP method (G3B3) [21], which are available in the NASA polynomial format in the supplement and in a popular database [19]. The reason for the adherence where possible to the G3B3 method is to provide to the chemical simulation performer consistent thermochemical data, which are calculated by the same reliable common method as all other compounds before. The temperature dependent results were without exception polynomialyzed by the same program [20].

Use of unrealistic thermochemical data for some substances, for example through simultaneously use of thermochemical data of different quality, in combination with a reliable chemical reaction model, result normally in wrong model prediction outputs (e.g. species time profiles, global parameter as flame velocities, ignition temperatures and ignition delay times), due to the use of thermochemical data during the automatically calculation of backward reaction rates within the simulation programs.

The polynomial NASA format, described in detail in the Introduction to Reference 19 , allows the user to calculate the original thermochemical ideal gas phase values of heat of formation, enthalpy, entropy, heat capacity and Gibbs free energy for temperatures between $200 \mathrm{~K}$ and $6000 \mathrm{~K}$ at a pressure of 1 bar. The maximal least square error due to the application of the fitting procedure to obtain the NASA polynomials was small; the highest value was less than $0.7 \%$ for the heat capacity values.

\section{CALCULATION METHODS}

The calculation of the thermochemistry data of the Silicon containing compounds was performed using Bonnie McBride's NASA PAC program (last updated 2003) [20]. To perform the thermodynamic calculations, the vibrations of the molecule are needed, as well as the molecules moments of inertia, the symmetry of the molecule, its statistical weight (1 
for neutral molecule 2 for a radical and the reverse value for the ion) and the standard enthalpy of formation of the molecule. If the molecule has internal hindered rotations, the rotor's moment of inertia, the rotor's symmetry and the rotation barrier were supplied instead of the pertinent low vibrations.

In most cases these molecular data were obtained by applying a variant of G3 theory, the G3//B3LYP variant or usually referred as G3B3 method, where the optimized structures, its moments of inertia, zero point vibrational energies and frequencies are calculated at the B3LYP/6-31G(d) level of theory. Following the recipe of Baboul et al. [21] the G3//B3LYP energy at $0 \mathrm{~K}$ can be calculated from the results obtained by sequential single point energy calculations with QCISDT(T,E4T)/6-31G(d); MP4/6$31+\mathrm{G}(\mathrm{d}) ; \mathrm{MP} 4 / 6-31 \mathrm{G}(2 \mathrm{df}, \mathrm{p})$ and at the end MP2(Full)/gen methods at the optimized structure obtained at the B3LYP/6-31G(d) level of theory. The data obtained were the atomization energies at $0 \mathrm{~K}$ and the enthalpies of formation at $0 \mathrm{~K}$ and $298.15 \mathrm{~K}$. The moments of inertia and vibrational frequencies were taken from the optimized chemical structure obtained from B3LYP/6-31G(d) calculations and were used without scaling, because in most cases these vibrations were closer to the experimental vibrations. These quantum chemical calculations were performed with the Gaussian 03 set of programs [22].

To prepare the input for the G3B3 method the molecule was drawn with the Chem3D program [23] and relaxed with the built in MOPAC semi empirical PM3 method [23]. Since Chem3D does not include double bonds for the silicon element, in these cases, the bonding had to be adjusted by hand and the optimization was done solely by the B3LYP/6-31-G(d) level of theory.

The determination of thermochemical data of ions can be done from studies of ion/molecule reactions, by optical spectroscopy and identification of a Rydberg series in a spectrum to get the ionization energy, by different electron or photoionization techniques such as threshold photoelectron-photoion coincidence (TPEPICO) technique or by ab initio calculations. To our knowledge there exist only a very limited number of thermochemical group additivity (GA) values calculated for ions of any kind.

The ions in this study were calculated as the rest of compounds by the G3B3 method and reported by the thermal electron convention. [See Introduction p.17 of Ref. 19].

The compounds containing the isotopes deuterium and tritium (D and $\mathrm{T})$ were calculated with the B3LYP/6-31G(d) to find their vibrations and moments of inertia. Their enthalpy of formation was calculated from the parent hydrogen molecule according to the formula: 
$\Delta_{\mathrm{f}} H^{\circ}(0 \mathrm{~K})_{\text {deuterated }}=$

$\Delta_{\mathrm{f}} H^{\circ}(0 \mathrm{~K})_{\text {undeuterated }}+\mathrm{n}\left[\Delta_{\mathrm{f}} H^{\circ}(0 \mathrm{~K})(\mathrm{D})-\Delta_{\mathrm{f}} H^{\circ}(0 \mathrm{~K})(\mathrm{H})\right]+E_{0 \text { deuterated }}-E_{0}$ undeuterated

where $\mathrm{n}$ is the number of isotope atoms in the molecule, and the zero point energy

$$
E_{0}=\left(\frac{1}{2} \sum_{i} v_{i}\right)(0.01196266) \mathrm{kJ} \mathrm{mol}^{-1} \text { using the vibrations } v_{i} \text { in } \mathrm{cm}^{-1} \text {. }
$$

A similar equation is used for tritium containing substances.

Since $\Delta_{\mathrm{f}} H^{\circ}(0 \mathrm{~K})(\mathrm{H})=216.034 \mathrm{~kJ} \mathrm{~mol}^{-1}, \quad \Delta_{\mathrm{f}} H^{\circ}(0 \mathrm{~K})(\mathrm{D})=219.804 \mathrm{~kJ} \mathrm{~mol}^{-1}[65]$ and $\Delta_{\mathrm{f}} H^{\circ}(0 \mathrm{~K})(\mathrm{T})=221.479 \mathrm{~kJ} \mathrm{~mol}^{-1}[5]$, the difference $\left[\Delta_{\mathrm{f}} H^{\circ}(0 \mathrm{~K})(\mathrm{D})-\Delta_{\mathrm{f}} H^{\circ}(0 \mathrm{~K})(\mathrm{H})\right]=3.77$ $\mathrm{kJ} \mathrm{mol}^{-1}$ and the according difference for tritium results in $5.445 \mathrm{~kJ} \mathrm{~mol}^{-1}$.

The calculations of the values of isotopic species is listed in Table S6 in the Supplement of this publication.

\section{RESULTS}

Thermodynamic data of two groups of silicon containing compounds were calculated. In the first group properties such as standard heat of formation, entropy and heat capacity of 112 inorganic silicon neutral species, radicals and ions were calculated.

A lot of attention is placed on silanes, the silicon hydride species, which are analogues substances to the hydrocarbon compounds. At standard conditions (STP), which are 1 bar and $298.15 \mathrm{~K}$, the monosilane and disilane are gaseous and very pyrophoric [53]. From trisilane on, the compounds are liquid at STP, but the pyrophoric property persists to hexasilane.

In the second group thermodynamic properties of 35 organic silicon containing species, including neutral radical and ionic compounds, were calculated.

The thermochemical properties of the species are listed in Tables 1 and 2 at $298.15 \mathrm{~K}$ at a standard pressure state of 1 bar. For the temperature range of $200 \mathrm{~K}$ to $6000 \mathrm{~K}$ the thermochemical properties of the species can be calculated from the 7 term NASA polynomials. They are listed for further use in chemical kinetics and computational fluid dynamics modelling software in Table S 5 in the supplement to this article, which is available free of charge. 


\section{DISCUSSION}

The Silicon containing closed shell compounds, their radicals and ions have been divided into two categories:

a) The inorganic 112 species

b) The 35 organic species

All species will be individually discussed below.

In general it should be taken into account that due to experimental problems the calorimetric values reported before 1970 are erroneous [1] and sometimes persist in further publications. Also because the different JANAF publications are reprints of the earlier calculations with a minimal number of new species, the year of the calculation of the pertinent specie is reported, and not the specific edition.

\section{$\mathrm{SiF}, \mathrm{SiF}^{+}, \mathrm{SiF}^{-}$, Monofluorosilicon and its ions.}

Monofluorosilicon was calculated according to the Huber and Herzberg constants for diatomic molecules [24] suggested by the NIST CCCBDB tables [25] with Irikura's [26] addition of $\omega_{\mathrm{e}} \mathrm{Y}_{\mathrm{e}}$. Standard heat of formation $\Delta_{\mathrm{f}} H^{\circ}(298 \mathrm{~K})=-62.6 \pm 8 \mathrm{~kJ} \mathrm{~mol}^{-1}$ and $\Delta_{\mathrm{f}} H^{\circ}(0 \mathrm{~K})=-63.78 \pm 8 \mathrm{~kJ} \mathrm{~mol}^{-1}$ were calculated with the G3B3 method. Michels and Hobbs (1993) [47] report for using G2 theory a $\Delta_{\mathrm{f}} H^{\circ}(298 \mathrm{~K})=-56.1 \mathrm{~kJ} \mathrm{~mol}^{-1}$, Feller and Dixon (1999) [43] report in a theoretical study for $0 \mathrm{~K} \Delta_{\mathrm{f}} H^{\circ}(0 \mathrm{~K})=-61.9 \pm 2 . \mathrm{kJ} \mathrm{mol}^{-1}$ in contradiction to JANAF (1976) tables [3], which reported a value of $\Delta_{\mathrm{f}} H^{\circ}(298 \mathrm{~K})=-20.08$ $\mathrm{kJ} \mathrm{mol}^{-1}$, Gurvich in 1991 [5] reported $\Delta_{\mathrm{f}} H^{\circ}(298 \mathrm{~K})=-25.23 \mathrm{~kJ} \mathrm{~mol}^{-1}$. This value was corrected by B.McBride to $-25.84 \mathrm{~kJ} \mathrm{~mol}^{-1}$.

The heat of formation of the ions $\mathrm{SiF}^{+}$and $\mathrm{SiF}^{-}$were calculated from the single vibration obtained from the B3LYP/6-31G(d) method as $\Delta_{\mathrm{f}} H^{\circ}(298 \mathrm{~K})=657.49 \pm 10 . \mathrm{kJ} \mathrm{mol}^{-1}$ and $\Delta_{\mathrm{f}} H^{\circ}(298 \mathrm{~K})=-87.87 \pm 10 . \mathrm{kJ} \mathrm{mol}^{-1}$ respectively, by the thermal electron convention. The error bar was enlarged, because only the single $\omega_{\mathrm{e}}$ vibration was available. The literature values found were for the cation $\operatorname{SiF}^{+} \Delta_{\mathrm{f}} H^{\circ}(298 \mathrm{~K})=712.90 \pm 9.2 \mathrm{~kJ} \mathrm{~mol}^{-1}$ by Weber and Armentrout (1988) [28] and for the anion $\mathrm{SiF}^{-}$Michels and Hobbs (1993) [47] report for a calculation with Gaussian 2-theory transformed to thermal electron convention $\Delta_{\mathrm{f}} H^{\circ}(298 \mathrm{~K})$ $=-140.9 \mathrm{~kJ} \mathrm{~mol}^{-1} ; \Delta_{\mathrm{f}} H^{\circ}(298 \mathrm{~K})=-103 \pm 11 \mathrm{~kJ} \mathrm{~mol}^{-1}$ was reported by Kawamata et al. (1996) [27]. 
$\mathrm{SiF}_{2}, \mathrm{SiF}_{2}^{+}, \mathrm{SiF}_{2}^{-}$, Silicondifluoride (Difluorosilylene) F-Si-F and its ions.

JANAF (1977) [3] lists $\Delta_{\mathrm{f}} H^{\circ}(298 \mathrm{~K})=-587.85 \mathrm{~kJ} \mathrm{~mol}^{-1}$; Gurvich (1991) [5] $\Delta_{\mathrm{f}} H^{\circ}(298 \mathrm{~K})=-592.8 . \mathrm{kJ} \mathrm{mol}^{-1}$ and Becerra and Walsh (1998) [6] report $\Delta_{\mathrm{f}} H^{\circ}(298 \mathrm{~K})=-$ 638. $\pm 6 . \mathrm{kJ} \mathrm{mol}^{-1}$ for difluorosilicon, which was calculated by Ho and Melius (1990) [10] as $\Delta_{\mathrm{f}} H^{\circ}(298 \mathrm{~K})=-627.0 \pm 17 . \mathrm{kJ} \mathrm{mol}^{-1}$. Michels and Hobbs $(1993)$ [47] report $\Delta_{\mathrm{f}} H^{\circ}(298 \mathrm{~K})=-$ $623.4 \mathrm{~kJ} \mathrm{~mol}^{-1}$; Feller and Dixon (1999) [43] report $\Delta_{\mathrm{f}} H^{\circ}(0 \mathrm{~K})=-634.7 \pm 2 . \mathrm{kJ} \mathrm{mol}^{-1}$ and the result of the present G3B3 calculation is $\Delta_{\mathrm{f}} H^{\circ}(0 \mathrm{~K})=-626.2 \pm 8 . \mathrm{kJ} \mathrm{mol}^{-1}$ and $\Delta_{\mathrm{f}} H^{\circ}(298 \mathrm{~K})=$ $-630.8 \pm 8 . \mathrm{kJ} \mathrm{mol}^{-1}$.

The heat of formation of the cation $\mathrm{SiF}_{2}{ }^{+}$using the G3B3 method is $\Delta_{\mathrm{f}} \mathrm{H}^{\circ}(298 \mathrm{~K})$ $=429.4 \pm 8 . \mathrm{kJ} \mathrm{mol}^{-1}$, and the anion results in $\Delta_{\mathrm{f}} H^{\circ}(298 \mathrm{~K})=-661 . \pm 8 . \mathrm{kJ} \mathrm{mol}^{-1}$ in thermal electron convention. Michels and Hobbs (1993) [47] report for the anion calculated by Gaussian 2-theory $\Delta_{\mathrm{f}} H^{\circ}(298 \mathrm{~K})=-651.8 \mathrm{~kJ} \mathrm{~mol}^{-1}$ in the thermal electron convention and Kawamata et al. (1996) [25] reports $\Delta_{\mathrm{f}} H^{\circ}(298 \mathrm{~K})=-608 \pm 22 . \mathrm{kJ} \mathrm{mol}^{-1}$ obtained from photoelectron spectroscopy experiments of binary cluster anions.

$\mathrm{O}=\mathrm{SiF}_{2}, \mathrm{O}=\mathrm{SiF}_{2}^{+}, \mathrm{O}=\mathrm{SiF}_{2}^{-}:$Difluorooxysilane and ions.

Heat of formation of difluorooxysilane was first reported by JANAF (1963) [3] as $\Delta_{\mathrm{f}} H^{\circ}(298 \mathrm{~K})=-966 . \mathrm{kJ} \mathrm{mol}^{-1}$ and the present G3B3 value is $\Delta_{\mathrm{f}} H^{\circ}(298 \mathrm{~K})=-899.0 \pm 8 . \mathrm{kJ} \mathrm{mol}^{-1}$. To our knowledge the thermochemical data of the ions were not published before, the thermal electron G3B3 values are $\Delta_{\mathrm{f}} H^{\circ}(298 \mathrm{~K})=247.4 \pm 8 . \mathrm{kJ} \mathrm{mol}^{-1}$ and $\Delta_{\mathrm{f}} H^{\circ}(298 \mathrm{~K})=-$ 1056. $\pm 8 . \mathrm{kJ} \mathrm{mol}^{-1}$ for the cation and anion respectively. The anion has no CAS No.

\section{$\mathrm{SiF}_{3}$, Trifluorosilicon radical (Trifluorosilyl)}

The heat of formation of the radical trifluorosilyl was published by JANAF (1977) [3] and Gurvich (1991) [5] as $\Delta_{\mathrm{f}} H^{\circ}(298 \mathrm{~K})=-996.2 . \mathrm{kJ} \mathrm{mol}^{-1}$. The present calculation taken from Ho and Melius (1990) [10] lists $\Delta_{\mathrm{f}} H^{\circ}(298 \mathrm{~K})=-993.3 \pm 8 . \mathrm{kJ} \mathrm{mol}^{-1}$. Michels and Hobbs (1993) [47] report for calculation with G2-theory $\Delta_{\mathrm{f}} H^{\circ}(298 \mathrm{~K})=-974.0 \mathrm{~kJ} \mathrm{~mol}^{-1}$, Becerra and Walsh (1998) [6] reported $\Delta_{\mathrm{f}} H^{\circ}(298 \mathrm{~K})=-987 \pm 20 . \mathrm{kJ} \mathrm{mol}^{-1}$. The unused G3B3 results in $\Delta_{\mathrm{f}} H^{\circ}(298 \mathrm{~K})=-988.47 \pm 8 . \mathrm{kJ} \mathrm{mol}^{-1}$.

\section{$\mathrm{SiHF}_{3}, \mathrm{SiHF}_{3}+$, Trifluorosilane and cation:}

JANAF (1976) [3] published for trifluorosilane $\Delta_{\mathrm{f}} H^{\circ}(298 \mathrm{~K})=-1200.8 \mathrm{~kJ} \mathrm{~mol}^{-1}$. The present calculation is based on Ho and Melius $(1990)[10] \Delta_{\mathrm{f}} H^{\circ}(298 \mathrm{~K})=-1207.7 \pm 5.4 \mathrm{~kJ}$ 
$\mathrm{mol}^{-1}$ : Becerra and Walsh (1998) [6] reported $\Delta_{\mathrm{f}} H^{\circ}(298 \mathrm{~K})=-1200 \pm 21 . \mathrm{kJ} \mathrm{mol}^{-1}$ and Takhistov and Golovin (2006) [48] propose $\Delta_{\mathrm{f}} H^{\circ}(298 \mathrm{~K})=-1198.7 \mathrm{~kJ} \mathrm{~mol}^{-1}$. The unused G3B3 value is $\Delta_{\mathrm{f}} H^{\circ}(298 \mathrm{~K})=-1193.5 \pm 8 . \mathrm{kJ} \mathrm{mol}^{-1}$.

The thermal electron G3B3 value for the cation was found $\Delta_{\mathrm{f}} H^{\circ}(298 \mathrm{~K})=73.2 \pm 8 \mathrm{~kJ} \mathrm{~mol}^{-1}$.

\section{$\mathrm{SiF}_{4}, \mathrm{SiF}_{4+}, \mathrm{SiF}_{4-}$, Tetrafluorosilane and ions.}

The standard heat of formation of tetrafluorosilane was published by JANAF (1976) [3] $\Delta_{\mathrm{f}} H^{\circ}(298 \mathrm{~K})=-1614.9 \mathrm{~kJ} \mathrm{~mol}^{-1}$; Walsh $(1983)$ [29] reports $\Delta_{\mathrm{f}} H^{\circ}(298 \mathrm{~K})=-1615 . \pm 1 . \mathrm{kJ}$ $\mathrm{mol}^{-1}$ and CODATA (1984) [50] recommended $\Delta_{\mathrm{f}} H^{\circ}(298 \mathrm{~K})=-1615.0 \pm 0.8 \mathrm{~kJ} \mathrm{~mol}^{-1}$. Michels and Hobbs (1993) [47] report for G2-method $\Delta_{\mathrm{f}} H^{\circ}(298 \mathrm{~K})=-1586.2 \mathrm{~kJ} \mathrm{~mol}^{-1}$. Feller and Dixon (1999) [43] report $\Delta_{\mathrm{f}} H^{\circ}(0 \mathrm{~K})=-1608.7 \pm 4 . \mathrm{kJ} \mathrm{mol}^{-1}$. The present calculation comes from Ho and Melius (1990) [10] and also Takhistov and Golovin (2006) [48] report $\Delta_{\mathrm{f}} H^{\circ}(298 \mathrm{~K})=-1615 . \pm 4.2 \mathrm{~kJ} \mathrm{~mol}^{-1}$. In 2001 Lyman and Noda [14] used the same values for the heat of formation, but calculated the harmonic oscillator as well as the anharmonic oscillator and found no differences below $1000 \mathrm{~K}$ for the thermodynamical data. Above this temperature the small difference is probably of little importance in combustion processes because $\mathrm{SiF}_{4}$ is normally not involved there, as well as in chemical vapor deposition processes, where the temperature is normally lower. The G3B3 calculation (unused) lists $\Delta_{\mathrm{f}} H^{\circ}(298 \mathrm{~K})=-1606 . \pm 8 . \mathrm{kJ} \mathrm{mol}^{-1}$.

The thermal electron G3B3 result for the $\mathrm{SiF}_{4}$ ions is $\Delta_{\mathrm{f}} H^{\circ}(298 \mathrm{~K})=-81.09 \pm 8 . \mathrm{kJ}$ $\mathrm{mol}^{-1}$ and $\Delta_{\mathrm{f}} H^{\circ}(298 \mathrm{~K})=-1544.08 \pm 8 . \mathrm{kJ} \mathrm{mol}^{-1}$ for the cation and anion respectively.

\section{$\mathrm{SiH}, \mathrm{SiH}+, \mathrm{SiH}-, \mathrm{SiD}, \mathrm{SiD}+, \mathrm{SiT}$, : Silicon hydride (Silylidyne), deutride and tritide and ions.}

The thermochemical data of the non-ionic mono hydrides, deuterides and tritides up to temperatures of $5000 \mathrm{~K}$ were first published by Haar, Friedman and Beckett in the NBS Monograph 20 (1961) [2], but the enthalpy of formation was not reported. The diatomic constants were taken from Huber and Herzberg [24]. The JANAF tables (1976) [3] report first for $\mathrm{SiH} \Delta_{\mathrm{f}} H^{\circ}(298 \mathrm{~K})=376.66 \pm 8.4 \mathrm{~kJ} \mathrm{~mol}^{-1}$, a value repeated by Boo \& Armentrout (1987) [8] and used here. Michels and Hobbs (1993) [47] report as G2-calculation result $\Delta_{\mathrm{f}} H^{\circ}(298 \mathrm{~K})=366.9 \mathrm{~kJ} \mathrm{~mol}^{-1}$, Katzer et al. (1997) [31] calculated $\Delta_{\mathrm{f}} H^{\circ}(298 \mathrm{~K})=372.6 \mathrm{~kJ}$ $\mathrm{mol}^{-1}$, Feller and Dixon (1999) [43] report from high level CCSD(T) calculation $\Delta_{\mathrm{f}} H^{\circ}(0 \mathrm{~K})$ $=366.0 \pm 1.7 \mathrm{~kJ} \mathrm{~mol}^{-1}$ and an experimental value of Berkowitz et al. (1987) [36] of $\Delta_{\mathrm{f}} H^{\circ}(0$ $\mathrm{K})=374.5 \pm 2.9 \mathrm{~kJ} \mathrm{~mol}^{-1}\left(\right.$ compared with our value of $\Delta_{\mathrm{f}} H^{\circ}(0 \mathrm{~K})=375.4 \pm 8 . \mathrm{kJ} \mathrm{mol}^{-1}$ ) and 
Jursic $(2000)[45,46]$ calculates $\Delta_{\mathrm{f}} H^{\circ}(0 \mathrm{~K})=369.0 \mathrm{~kJ} \mathrm{~mol}^{-1}$. Finally M.C. Lin and coworkers report (2013)[60] $\Delta_{\mathrm{f}} H^{\circ}(0 \mathrm{~K})=370.7$ to $374.9 \pm 5 . \mathrm{kJ} \mathrm{mol}^{-1}$.

Standard heat of formation of SiD is mentioned by HSC database (1999) [34] as $\Delta_{\mathrm{f}} H^{\circ}(298 \mathrm{~K})=368.7 \mathrm{~kJ} \mathrm{~mol}^{-1}$. This value was adopted by us. The diatomic constants were taken from Huber \& Herzberg [24].

SiT Silicontritide was reported by the HSC database [34] from a Russian unidentified reference as $\Delta_{\mathrm{f}} H^{\circ}(298 \mathrm{~K})=369.1 \mathrm{~kJ} \mathrm{~mol}^{-1}$ which was used here.

Grev and Schaefer (1992) [44] calculated for $\mathrm{SiH}^{+} \Delta_{\mathrm{f}} H^{\circ}(0 \mathrm{~K})=1139.5 \mathrm{~kJ} \mathrm{~mol}^{-1}$. M.C. Lin and Coworkers (2017) [61] found $\Delta_{\mathrm{f}} H^{\circ}(298 \mathrm{~K})=1149.4 \mathrm{~kJ} \mathrm{~mol}^{-1}$. The heat of formation for $\mathrm{SiH}^{+}$was taken from Boo and Armentrout [8] as $\Delta_{\mathrm{f}} H^{\circ}(298 \mathrm{~K})=1144.3 \pm 8 . \mathrm{kJ}$

$\mathrm{mol}^{-1}$ and for $\mathrm{SiH}^{-}$the G3B3 result in thermal electron convention is $\Delta_{\mathrm{f}} H^{\circ}(298 \mathrm{~K})=298.8 \pm 8$. $\mathrm{kJ} \mathrm{mol}^{-1}$. Michels and Hobbs (1993) [47] report for $\mathrm{SiH}^{-}$using the $\mathrm{G} 2$ method in thermal electron convention transformed value of $\Delta_{\mathrm{f}} H^{\circ}(298 \mathrm{~K})=246.5 \mathrm{~kJ} \mathrm{~mol}^{-1}$.

SiD+ was suggested by Boo and Armentrout [8] as $\Delta_{\mathrm{f}} H^{\circ}(298 \mathrm{~K})=1145.16 \mathrm{~kJ} \mathrm{~mol}^{-1}$ and used here.

$\mathrm{SiD}_{2}, \mathrm{SiD}_{2}^{+}, \mathrm{SiD}_{2}^{-}:$Silylene-D2 and ions.

This compound was reported by Boo and Armentrout (1987) [8] as $\Delta_{\mathrm{f}} H^{\circ}(298 \mathrm{~K})=295.4 \pm 10$. $\mathrm{kJ} \mathrm{mol}{ }^{-1}$. Based on $\Delta_{\mathrm{f}} H^{\circ}(0 \mathrm{~K}) \mathrm{SiH}_{2}=265.5 \pm 8 . \mathrm{kJ} \mathrm{mol}^{-1}$ we obtain for $\mathrm{SiD}_{2}$ the value of $\Delta_{\mathrm{f}} H^{\circ}(0 \mathrm{~K})=264.4 \pm 8 . \mathrm{kJ} \mathrm{mol}^{-1}\left(\Delta_{\mathrm{f}} H^{\circ}(298 \mathrm{~K})=262.8 \pm 8 . \mathrm{kJ} \mathrm{mol}^{-1}\right)$.

The cation $\mathrm{SiD}_{2}{ }^{+}$was also reported by Boo and Armentrout [8] $\Delta_{\mathrm{f}} H^{\circ}(298 \mathrm{~K})$ $=1160.6 \pm 6 . \mathrm{kJ} \mathrm{mol}^{-1}$, and based on G3B3 $\Delta_{\mathrm{f}} H^{\circ}(0 \mathrm{~K}) \mathrm{SiH}_{2}+=1152.34 \pm 8 . \mathrm{kJ} \mathrm{mol}^{-1}$ we obtain for $\mathrm{SiD}_{2}+\Delta_{\mathrm{f}} H^{\circ}(0 \mathrm{~K})=1150.9 \pm 8 . \mathrm{kJ} \mathrm{mol}^{-1}\left(\Delta_{\mathrm{f}} H^{\circ}(298 \mathrm{~K})=1155.6 \pm 8 . \mathrm{kJ} \mathrm{mol}^{-1}\right)$. The anion $\mathrm{SiD}_{2}{ }^{-}$was not reported in the literature and the present calculation shows $\Delta_{\mathrm{f}} H^{\circ}(0 \mathrm{~K})$ $=161.2 \pm 8 . \mathrm{kJ} \mathrm{mol}^{-1}\left(\Delta_{\mathrm{f}} H^{\circ}(298 \mathrm{~K})=147.3 \pm 8 . \mathrm{kJ} \mathrm{mol}^{-1}\right)$ The ions at $298 \mathrm{~K}$ are reported in the thermal electron convention.

\section{$\mathrm{SiHT}_{3}$ Tritritiumsilane T3:}

This tritium compound is published only by the Russian Glushko, Gurvich et al. edition (1970) [4] $\Delta_{\mathrm{f}} H^{\circ}(298 \mathrm{~K})=27.5 \mathrm{~kJ} \mathrm{~mol}^{-1}$. The present calculation based on $\Delta_{\mathrm{f}} H^{\circ}(0 \mathrm{~K})$ $\left(\mathrm{SiH}_{4}\right)=44.3 \mathrm{~kJ} \mathrm{~mol}^{-1}$ result in $\Delta_{\mathrm{f}} H^{\circ}(298 \mathrm{~K})=27.610 \mathrm{~kJ} \mathrm{~mol}^{-1}\left(\Delta_{\mathrm{f}} H^{\circ}(0 \mathrm{~K})=36.13 \mathrm{~kJ} \mathrm{~mol}^{-1}\right)$. 


\section{$\mathrm{SiH}_{2}$ Singlet and Triplet, $\mathrm{SiH}_{2}^{+}, \mathrm{SiH}_{2}^{-}$: Silylene and their ions.}

The singlet of Silylene ${ }^{1} \mathrm{SiH}_{2}$ is reported by Boo and Armentrout (1987) [8] with $\Delta_{\mathrm{f}} H^{\circ}(298 \mathrm{~K})=288.7 \pm 8.4 \mathrm{~kJ} \mathrm{~mol}^{-1}$; by Michels and Hobbs (1993) [47] as G2-calculation result $\Delta_{\mathrm{f}} H^{\circ}(298 \mathrm{~K})=260.2 \mathrm{~kJ} \mathrm{~mol}^{-1}$, by Katzer et al. (1997) [31] as $\Delta_{\mathrm{f}} H^{\circ}(298 \mathrm{~K})=272.9 \mathrm{~kJ}$ $\mathrm{mol}^{-1}$; by Becerra and Walsh (1998) [6] as $\Delta_{\mathrm{f}} H^{\circ}(298 \mathrm{~K})=273 \pm 2 . \mathrm{kJ} \mathrm{mol}^{-1}$, by Feller and Dixon (1999) [43] $\Delta_{\mathrm{f}} H^{\circ}(0 \mathrm{~K})=268.2 \pm 1.6 \mathrm{~kJ} \mathrm{~mol}^{-1}$, by Jursic (2000) [45] $\Delta_{\mathrm{f}} H^{\circ}(0 \mathrm{~K})=279.0$ $\mathrm{kJ} \mathrm{mol}^{-1}$, by Sukkaew et al. (2014) [16] using G4 and G4(MP2) calculations as $\Delta_{\mathrm{f}} H^{\circ}(298 \mathrm{~K})$ $=265.1$ and $262.0 \mathrm{~kJ} \mathrm{~mol}^{-1}$ respectively. A value of $\Delta_{\mathrm{f}} H^{\circ}(298 \mathrm{~K})=263 . \mathrm{kJ} / \mathrm{mol}(62.87$ $\mathrm{kcal} / \mathrm{mol}$ ) is obtained within the RMG-SiliconHydrideLibary thermochemical data in NASA format as provided by West and coworkers (2016) [18] within the chem_annotated.inp- file of the supplement. The present G3B3 calculation result for the singlet Silylene is $\Delta_{\mathrm{f}} H^{\circ}(298 \mathrm{~K})=263.8 \pm 8 . \mathrm{kJ} \mathrm{mol}^{-1}\left(\Delta_{\mathrm{f}} H^{\circ}(0 \mathrm{~K})=265.5 \pm 8 . \mathrm{kJ} \mathrm{mol}^{-1}\right)$.

The triplet Silylene ${ }^{3} \mathrm{SiH}_{2}$ is reported by Michels and Hobbs (1993) [47] for G2 method usage as $\Delta_{\mathrm{f}} H^{\circ}(298 \mathrm{~K})=358.2 \mathrm{~kJ} \mathrm{~mol}^{-1}$; by Katzer et al. (1997) [31] as $\Delta_{\mathrm{f}} H^{\circ}(298 \mathrm{~K})$ $=355.2 \mathrm{~kJ} \mathrm{~mol}^{-1}$; by Feller and Dixon (1999) [43] as $\Delta_{\mathrm{f}} H^{\circ}(0 \mathrm{~K})=357.3 \pm 1.6 \mathrm{~kJ} \mathrm{~mol}^{-1}$, by Jursic (2000) $[45,46] \Delta_{\mathrm{f}} H^{\circ}(0 \mathrm{~K})=362.8 \mathrm{~kJ} \mathrm{~mol}^{-1}$; by Sukkaew et al. (2014) [16] using G4 and G4(MP2) methods as $\Delta_{\mathrm{f}} H^{\circ}(298 \mathrm{~K})=359.9$ and $355.2 . \mathrm{kJ} \mathrm{mol}^{-1}$ respectively. The G3B3 value is $\Delta_{\mathrm{f}} H^{\circ}(298 \mathrm{~K})=354.6 \pm 8 . \mathrm{kJ} \mathrm{mol}^{-1}$.

For the cation $\mathrm{SiH}_{2}{ }^{+}$the thermal electron value of Nguyen et al (2017) [61] is $\Delta_{\mathrm{f}} H^{\circ}(298 \mathrm{~K})=1161.4 .-1164.9 \mathrm{~kJ} \mathrm{~mol}^{-1}$. It was also reported by Boo and Armentrout [8] $\Delta_{\mathrm{f}} H^{\circ}(298 \mathrm{~K})=1155.2 \pm 7 . \mathrm{kJ} \mathrm{mol}^{-1}$. and the G3B3 calculation results gives a value for the heat of formation of $\Delta_{\mathrm{f}} H^{\circ}(298 \mathrm{~K})=1156.9 . \pm 8 . \mathrm{kJ} \mathrm{mol}^{-1}$.

The anion $\mathrm{SiH}_{2}{ }^{-}$was calculated by Michels and Hobbs (1993) [47] with G2 method in ion convention. Transformation in thermal convention by subtraction of $6.197 \mathrm{~kJ} / \mathrm{mol}$ per negative charge results in a value of $\Delta_{\mathrm{f}} H^{\circ}(298 \mathrm{~K})=158.6 \mathrm{~kJ} \mathrm{~mol}^{-1}$, our G3B3 calculation produces a value of $\Delta_{\mathrm{f}} H^{\circ}(298 \mathrm{~K})=153.7 . \pm 8 . \mathrm{kJ} \mathrm{mol}^{-1}$. All ion values are reported in the thermal electron convention.

\section{$\mathrm{SiH}_{2} \mathrm{~T}_{2}:$ Silane-T , Ditritiumsilane.}

This tritium compound was reported only in the old Russian publication of Glushko, Gurvich, et al. (1970) [4] $\Delta_{\mathrm{f}} H^{\circ}(298 \mathrm{~K})=29.6 \mathrm{~kJ} \mathrm{~mol}^{-1}$. The present calculation based on $\Delta_{\mathrm{f}} H^{\circ}(0 \mathrm{~K})\left(\mathrm{SiH}_{4}\right)=44.3 \mathrm{~kJ} \mathrm{~mol}^{-1}$ lists $\Delta_{\mathrm{f}} H^{\circ}(298 \mathrm{~K}) 30.09 \mathrm{~kJ} \mathrm{~mol}^{-1}\left(\Delta_{\mathrm{f}} H^{\circ}(0 \mathrm{~K})=39.08\right.$ $\left.\mathrm{kJ} \mathrm{mol}^{-1}\right)$. 
$\mathrm{SiH}_{3}, \mathrm{SiH}_{3}^{+}, \mathrm{SiH}_{3}^{-}:$Silyl radical and ions.

Silyl was reported by Boo and Armentrout (1987) [8] as $\Delta_{\mathrm{f}} H^{\circ}(298 \mathrm{~K})=202.9 \mathrm{~kJ}$ $\mathrm{mol}^{-1}$; by Ho and Melius (1990) [10] $\Delta_{\mathrm{f}} H^{\circ}(298 \mathrm{~K})=198.5 \pm 4.2 . \mathrm{kJ} \mathrm{mol}^{-1}$; by Gurvich (1991) [5] $\Delta_{\mathrm{f}} H^{\circ}(298 \mathrm{~K})=197.7 \mathrm{~kJ} \mathrm{~mol}^{-1}$; Michels and Hobbs (1993) [47] report for G2 method $\Delta_{\mathrm{f}} H^{\circ}(298 \mathrm{~K})=194.6 \mathrm{~kJ} \mathrm{~mol}^{-1}$; Ochterski et al. (1995) [7] $\Delta_{\mathrm{f}} H^{\circ}(298 \mathrm{~K})=200 . \mathrm{kJ} \mathrm{mol}^{-1}$ as well as Katzer et al (1997) [31], Beccerra and Walsh (1998) [6] report $\Delta_{\mathrm{f}} H^{\circ}(298 \mathrm{~K})=200.5 \pm 2 \mathrm{~kJ}$ $\mathrm{mol}^{-1}$. Feller and Dixon (1999) [43] report $\Delta_{\mathrm{f}} H^{\circ}(0 \mathrm{~K})=197.9 \mathrm{~kJ} \mathrm{~mol}^{-1}$; Jursic (2000) [45] $\Delta_{\mathrm{f}} H^{\circ}(0 \mathrm{~K})=209.2 \mathrm{~kJ} \mathrm{~mol}^{-1}$ and Sukkaew et al. (2014) [16] as $\Delta_{\mathrm{f}} H^{\circ}(298 \mathrm{~K})=197.7 \mathrm{~kJ} \mathrm{~mol}^{-1}$ using G4 and $\Delta_{\mathrm{f}} H^{\circ}(298 \mathrm{~K})=193.7 \mathrm{~kJ} \mathrm{~mol}^{-1}$ with G4(MP2) method. The present G3B3 result is $\Delta_{\mathrm{f}} H^{\circ}(298 \mathrm{~K})=195.6 \pm 8 . \mathrm{kJ} \mathrm{mol}^{-1}$.

The cation $\mathrm{SiH}_{3}{ }^{+}$was listed by Boo and Armentrout (1987) [8] as $\Delta_{\mathrm{f}} H^{\circ}(298 \mathrm{~K})$ $=992 . \pm 8 . \mathrm{kJ} \mathrm{mol}^{-1}$, Grev and Schaefer (1992) [44] calculated $\Delta_{\mathrm{f}} H^{\circ}(0 \mathrm{~K})=989.9 \pm 6 . \mathrm{kJ} \mathrm{mol}^{-1}$; Nguyen et al (2017) [61] using CCSD(T)/CBS report $\Delta_{\mathrm{f}} H^{\circ}(298 \mathrm{~K})=999.8 \pm 5 . \mathrm{kJ} \mathrm{mol}^{-1}$, and the present G3B3 lists $\Delta_{\mathrm{f}} H^{\circ}(298 \mathrm{~K})=988.9 \pm 8 . \mathrm{kJ} \mathrm{mol}^{-1}$ all results of the ions are in thermal electron convention.

The anion $\mathrm{SiH}_{3}{ }^{-}$was reported by Michels and Hobbs (1993) [47] for $\mathrm{G} 2$ method in ion convention, which excludes the enthalpy of the electron. Transformation to thermal convention through subtraction of $6.197 \mathrm{~kJ} / \mathrm{mol}$ per negative charge results in $\Delta_{\mathrm{f}} H^{\circ}(298 \mathrm{~K})$ $=51.5 \mathrm{~kJ} \mathrm{~mol}^{-1}$ and the G3B3 calculation was $\Delta_{\mathrm{f}} H^{\circ}(298 \mathrm{~K})=52.3 \pm 8 . \mathrm{kJ} \mathrm{mol}^{-1}$. The ions are reported in the thermal electron convention.

\section{$\mathrm{SiD}_{3} \mathrm{SiD}_{3}+\mathrm{SiD}_{3^{-}}$Silyl-D3 and ions.}

For the deuterated silyl radical. Boo and Armentrout (1987) [8] reported $\Delta_{\mathrm{f}} H(298$ $\mathrm{K})=198.7 \pm 8 . \mathrm{kJ} \mathrm{mol}^{-1}$. The present calculation based on $\Delta_{\mathrm{f}} H(0 \mathrm{~K})\left(\mathrm{SiH}_{3}\right)=201.090 \pm 8 . \mathrm{kJ}$ $\mathrm{mol}^{-1}$ is $\Delta_{\mathrm{f}} H(0 \mathrm{~K})=196.8 \pm 8 . \mathrm{kJ} \mathrm{mol}^{-1}$ for $\mathrm{SiD}_{3}\left(\Delta_{\mathrm{f}} H(298)==191.8 \pm 8 . \mathrm{kJ} \mathrm{mol}^{-1}\right)$.

The cation $\mathrm{SiD}_{3}+$ was reported by Boo and Armentrout [8] $\Delta_{\mathrm{f}} \mathrm{H}(298 \mathrm{~K})=996.9 \pm 8$. $\mathrm{kJ} \mathrm{mol}^{-1}$. The present calculation based on $\Delta_{\mathrm{f}} H(0 \mathrm{~K})\left(\mathrm{SiH}_{3}+\right)=988.206 \pm 8 . \mathrm{kJ} \mathrm{mol}^{-1}$ as a value obtained from G3B3 calculation results in $\Delta_{\mathrm{f}} H(0 \mathrm{~K})\left(\mathrm{SiD}_{3}+\right)=988.839 \pm 8 . \mathrm{kJ} \mathrm{mol}^{-1}$ $\left(\Delta \mathrm{f} H(298 \mathrm{~K})=996.13 \pm 8 . \mathrm{kJ} \mathrm{mol}^{-1}\right)$.

The anion $\mathrm{SiD}_{3}{ }^{-}$is calculated for the first time from $\Delta_{\mathrm{f}} H(0 \mathrm{~K}) \mathrm{SiH}_{3}=64.053 \mathrm{~kJ} \mathrm{~mol}^{-1}$ and the value obtained is $\Delta_{\mathrm{f}} H^{\circ}(298 \mathrm{~K})=37.431 \pm 8 . \mathrm{kJ} \mathrm{mol}^{-1}\left(\Delta_{\mathrm{f}} H^{\circ}(0 \mathrm{~K})=55.003 \pm 8 . \mathrm{kJ}\right.$ $\mathrm{mol}^{-1}$. The ions are reported in the thermal electron convention. 


\section{$\mathrm{SiH}_{3} \mathrm{~T}$ Silane-T (Monotritiumsilane).}

Monotritiumsilane was reported in the Russian publication of Glushko, Gurvich et al. (1970) [4] as $\Delta_{\mathrm{f}} H^{\circ}(298 \mathrm{~K})=32.2 . \mathrm{kJ} \mathrm{mol}^{-1}$. The calculation based on $\Delta_{\mathrm{f}} H^{\circ}(0 \mathrm{~K})\left(\mathrm{SiH}_{4}\right)$ ${ }_{i}=44.319 \mathrm{~kJ} \mathrm{~mol}^{-1}$ resulted in $\Delta_{\mathrm{f}} H^{\circ}(0 \mathrm{~K})=41.815 \pm 8 . \mathrm{kJ} \mathrm{mol}^{-1} \Delta_{\mathrm{f}} H^{\circ}(298 \mathrm{~K})=32.451 \pm 8 . \mathrm{kJ}$ $\mathrm{mol}^{-1}$.

\section{$\mathrm{SiH}_{4}, \mathrm{SiH}_{4}^{+}, \mathrm{SiD}_{4}, \mathrm{SiT}_{4},:$ Silane and Silane cation, Silane-D4 and Silane-T4.}

$\mathrm{SiH}_{4}$ is a pyrophoric gas at STP and was proposed to be used as igniter of Hydrogen jets instead of a spark. $\mathrm{SiH}_{4}$ was calculated by JANAF (1976) [3] $\Delta_{\mathrm{f}} H^{\circ}(298 \mathrm{~K})=34.3 \pm 2$. kJ $\mathrm{mol}^{-1}$. Ho and Melius (1990) [10] report $\Delta_{\mathrm{f}} H^{\circ}(298 \mathrm{~K})=34.3 \mathrm{~kJ} \mathrm{~mol}^{-1}$ as well as Takhistov and Golovin (2006) [48] . Michels and Hobbs (1993) [47] report for G2 method $\Delta_{\mathrm{f}} H^{\circ}(298 \mathrm{~K})$ $=24.7 \mathrm{~kJ} \mathrm{~mol}^{-1}$, Katzer et al. (1997) [31] $\Delta_{\mathrm{f}} H^{\circ}(298 \mathrm{~K})=34.4 \mathrm{~kJ} \mathrm{~mol}^{-1}$, Feller and Dixon (1999) [43] report $\Delta_{\mathrm{f}} H^{\circ}(0 \mathrm{~K})=36.4 \pm 2 . \mathrm{kJ} \mathrm{mol}^{-1}$. Jursic (2000) [45] reports for the CBSQ calculation $\Delta_{\mathrm{f}} H^{\circ}(0 \mathrm{~K})=42.3 \mathrm{~kJ} \mathrm{~mol}^{-1}$. Broadbelt and coworkers (2004) [9] calculated $\Delta_{\mathrm{f}} H^{\circ}(298 \mathrm{~K})=33.9 \mathrm{~kJ} \mathrm{~mol}^{-1}$ using bond additivity correction ( BAC). Hidding and Pfitzner (2006) [53] report $\Delta_{\mathrm{f}} H^{\circ}(298 \mathrm{~K})=34.5 \mathrm{~kJ} \mathrm{~mol}^{-1}$. Gurvich's (1991) [5] value $\Delta_{\mathrm{f}} H^{\circ}(298 \mathrm{~K})$ $=34.7 \pm 1.5 \mathrm{~kJ} \mathrm{~mol}^{-1}$ was used for calculation of the polynomials. The G3B3 value found $\Delta_{\mathrm{f}} H^{\circ}(298 \mathrm{~K})=30.1 \pm 8 . \mathrm{kJ} \mathrm{mol}^{-1}$ was lower than all other values in literature although within the error range reported. The value of $\Delta_{\mathrm{f}} H^{\circ}(298 \mathrm{~K})=23.3 \mathrm{~kJ} \mathrm{~mol}^{-1}$ was calculated from the NASA polynomials of thermochemical data within the RMG-SiliconHydrideLibary taken from chem_annotated.inp-file of the supplement of West and coworkers 2016 [18] .

Boo and Armentrout [8] do not report a definite $\mathrm{SiD}_{4}$ heat of formation. The calculation was based on $\Delta_{\mathrm{f}} H^{\circ}(0 \mathrm{~K})\left(\mathrm{SiH}_{4}\right)$ which yields $\Delta_{\mathrm{f}} H^{\circ}(0 \mathrm{~K})=31.6 \pm 8 . \mathrm{kJ} \mathrm{mol}^{-1}$ $\left(\Delta_{\mathrm{f}} H^{\circ}(298 \mathrm{~K})==22.8 \pm 8 . \mathrm{kJ} \mathrm{mol}^{-1}\right)$.

Thermochemical data of $\mathrm{SiT}_{4}$ Tetratritiumsilane is calculated for the first time based on $\Delta_{\mathrm{f}} H^{\circ}(0 \mathrm{~K})\left(\mathrm{SiH}_{4}\right)=44.3 \pm 8 . \mathrm{kJ} \mathrm{mol}^{-1}$, which result in $\Delta_{\mathrm{f}} H^{\circ}(0 \mathrm{~K})=25.33 \pm 8 . \mathrm{kJ} \mathrm{mol}^{-1}$ $\left(\Delta_{\mathrm{f}} H^{\circ}(298 \mathrm{~K})=17.3 \pm 8 . \mathrm{kJ} \mathrm{mol}^{-1}\right)$.

The cation $\mathrm{SiH}_{4}{ }^{+}$was calculated by Nguyen et al (2017) [63] at the CCSD(T)/CBS method thermal electron is $\Delta_{\mathrm{f}} H^{\circ}(298 \mathrm{~K})=1120.4 \mathrm{~kJ} \mathrm{~mol}^{-1}$. Our calculation was performed according to the NIST CCCBDB [25] B3LYP/6-31G(d) vibrations and moments of inertia. The present thermal electron G3B3 value is $\Delta_{\mathrm{f}} H^{\circ}(298 \mathrm{~K})=1144.6 \pm 8 . \mathrm{kJ} \mathrm{mol}^{-1}$. 
$\mathrm{SiO}, \mathrm{SiO}^{+}, \mathrm{SiO}^{-}:$Oxosilyum and ions.

The constants for diatomic molecule $\mathrm{SiO}$ were taken from Huber and Herzberg (1977) [24]. The calculated G3B3 enthalpy of formation was $\Delta_{\mathrm{f}} H^{\circ}(298 \mathrm{~K})=-102.2 \pm 8$. kJ $\mathrm{mol}^{-1}$. JANAF (1967) [3] reports $\Delta_{\mathrm{f}} H^{\circ}(298 \mathrm{~K})=-100.4 \pm 8 . \mathrm{kJ} \mathrm{mol}^{-1}$. Gurvich (1994) [5] reports $\Delta_{\mathrm{f}} H^{\circ}(298 \mathrm{~K})=-98.7 \mathrm{~kJ} \mathrm{~mol}^{-1}$.

No mention in the literature was found for the ions. The calculated thermal electron G3B3 values for the cation $\mathrm{SiO}^{+}$and the anion $\mathrm{SiO}^{-}$is $\Delta_{\mathrm{f}} H^{\circ}(298 \mathrm{~K})=1020.5 \pm 8 . \mathrm{kJ} \mathrm{mol}^{-1}$ and $\Delta_{\mathrm{f}} H^{\circ}(298 \mathrm{~K})=-117.0 \pm 8 . \mathrm{kJ} \mathrm{mol}^{-1}$ respectively.

\section{$\mathrm{SiO}_{2}, \mathrm{SiO}_{2}^{-}$Silica and anion.}

The $\mathrm{SiO}_{2}$ gas compound was calculated using the NIST CCCBDB [25] vibrations and $\mathrm{B}_{0}$ rotation constant (for their G3B3 method). The enthalpy of formation was taken from Gurvich (1989) [5] $\Delta_{\mathrm{f}} H^{\circ}(298 \mathrm{~K})=-322.1 \pm 10 . \mathrm{kJ}^{\mathrm{mol}}{ }^{-1}$. McBride in the corrected NASA database reported the same value. JANAF (1967) [3] reports $\Delta_{\mathrm{f}} H^{\circ}(298 \mathrm{~K})=-305.4 \mathrm{~kJ}$ $\mathrm{mol}^{-1}$ and Benson (1976) [33] by the Group Additivity method estimated $\Delta_{\mathrm{f}} H^{\circ}(298 \mathrm{~K})=$ $-318 . \pm 12 . \mathrm{kJ} \mathrm{mol}^{-1}$.

The anion thermochemistry is mentioned in the literature by Wang, Wu et al. (1996) [51] $\Delta_{\mathrm{f}} H^{\circ}(298 \mathrm{~K})=-531 . \mathrm{kJ} \mathrm{mol}^{-1}$ as an estimate, and the present thermal electron G3B3 lists $\Delta_{\mathrm{f}} H^{\circ}(298 \mathrm{~K})=-488.4 \pm 8 . \mathrm{kJ} \mathrm{mol}^{-1}$.

\section{$\mathrm{Si}_{2} \mathrm{~F}_{6}, \mathrm{Si}_{2} \mathrm{~F}_{6}{ }^{+}, \mathrm{Si}_{2} \mathrm{~F}_{6}{ }^{-}$: Hexafluorodisilane $\mathrm{F}_{3} \mathrm{Si}-\mathrm{SiF}_{3}$ and ions.}

Standard heat of formation of $\mathrm{F}_{3} \mathrm{Si}_{-} \mathrm{SiF}_{3}$ was reported by Ho and Melius (1990) [10] as $\Delta_{\mathrm{f}} H^{\circ}(298 \mathrm{~K})=-2383.3 \pm 14.5 \mathrm{~kJ} \mathrm{~mol}^{-1}$. This value vas used in 2001 by Lyman [14] as well as in the NASA database [37] where the value was erroneously referenced to Lymann and is included in the HSC database [34] too. The present G3B3 calculation lists $\Delta_{\mathrm{f}} H^{\circ}(298 \mathrm{~K})=-2346 \pm 7 . \mathrm{kJ} \mathrm{mol}^{-1}$.

The cation $\mathrm{Si}_{2} \mathrm{~F}_{6}{ }^{+}$and anion $\mathrm{Si}_{2} \mathrm{~F}_{6}{ }^{-}$thermochemistry are calculated for the first time and their thermal electron G3B3 values are $\Delta_{\mathrm{f}} H^{\circ}(298 \mathrm{~K})=-1205 . \pm 8 . \mathrm{kJ} \mathrm{mol}^{-1}$ and $\Delta_{\mathrm{f}} H^{\circ}(298 \mathrm{~K})=-2401.7 \pm 8 . \mathrm{kJ} \mathrm{mol}^{-1}$ respectively. The cation has no CAS number.

\section{$\mathrm{Si}_{2} \mathrm{OF}_{6}$ Hexafluorodisiloxane $\mathrm{F}_{3} \mathrm{Si}-\mathrm{O}-\mathrm{SiF}_{3}$}

This compound was listed in the HSC thermal database [34] as $\Delta_{\mathrm{f}} H^{\circ}(298 \mathrm{~K})=$ $-2904.0 \pm 8 . \mathrm{kJ} \mathrm{mol}^{-1}$ and the present G3B3 value is $\Delta_{\mathrm{f}} H^{\circ}(298 \mathrm{~K})=-2865.8 \pm 8 . \mathrm{kJ} \mathrm{mol}^{-1}$. 


\section{$\mathrm{Si}_{2} \mathrm{H}, \mathrm{Si}_{2} \mathrm{D}$ Disilyne Hydride and Deuteride radicals $\mathrm{HSi}=\mathrm{Si}{ }^{*} \mathrm{DSi}=\mathrm{Si}^{*}$.}

Boo and Armentrout (1987) [8] quote Walsh for a value of $\Delta_{\mathrm{f}} H^{\circ}(298 \mathrm{~K})$ $=603.3 \pm 12.5 . \mathrm{kJ} \mathrm{mol}^{-1}$. Curtiss et al (1991) [57] using G2 method report $\Delta_{\mathrm{f}} H^{\circ}(0 \mathrm{~K})=532.2$ $\mathrm{kJ} \mathrm{mol}^{-1}$. The G3B3 calculation showed $\Delta_{\mathrm{f}} H^{\circ}(0 \mathrm{~K})=492.25 \pm 8 . \mathrm{kJ} \mathrm{mol}^{-1}$. $\left(\Delta_{\mathrm{f}} H^{\circ}(298 \mathrm{~K})\right.$ $=492.18 \pm 8 . \mathrm{kJ} \quad \mathrm{mol}^{-1}$ ).

The enthalpy of formation of $\mathrm{DSi} \equiv \mathrm{Si}^{*}$ was calculated from the enthalpy $\Delta_{\mathrm{f}} H^{\circ}(0 \mathrm{~K})$ of $\mathrm{Si}_{2} \mathrm{H}$ and lists $\Delta_{\mathrm{f}} H^{\circ}(0 \mathrm{~K})=491.3 \pm 8 . \mathrm{kJ} \mathrm{mol}^{-1}$. $\left(\Delta_{\mathrm{f}} H^{\circ}(298 \mathrm{~K})=493.18 \pm 8 . \mathrm{kJ} \mathrm{mol}^{-1}\right)$.

\section{$\mathrm{Si}_{2} \mathrm{H}_{2}, \mathrm{Si}_{2} \mathrm{H}_{2}+, \mathrm{Si}_{2} \mathrm{D}_{2}$ Disilyne $\mathrm{HSi} \equiv \mathrm{SiH}$ cation and disilyne-D2}

This compound that resembles acetylene vas reported first by Katzer et. al (1997) [31] as $\Delta_{\mathrm{f}} H^{\circ}(298 \mathrm{~K})=464.4 \mathrm{~kJ} \mathrm{~mol}^{-1}$. Broadbelt and coworkers (2004) [9] report $\Delta_{\mathrm{f}} H^{\circ}(298 \mathrm{~K})=454 . \mathrm{kJ} \mathrm{mol}^{-1}$ using G3B3 calculation. $\Delta_{\mathrm{f}} H^{\circ}(298 \mathrm{~K})=374.5 . \mathrm{kJ} \mathrm{mol}^{-1}$ is reported by Boo and Armentrout (1987) [8]. The present G3B3 calculation lists $\Delta_{\mathrm{f}} H^{\circ}(298 \mathrm{~K})=452.1 . \pm 8 . \mathrm{kJ} \mathrm{mol}^{-1}$.

Boo and Armentrout (1987) [8] suggested for the cation $\mathrm{HSi} \equiv \mathrm{SiH}+$ an upper limit of $\Delta_{\mathrm{f}} H^{\circ}(298 \mathrm{~K})=1121.3 \pm 10.9 \mathrm{~kJ} \mathrm{~mol}^{-1}$ but obtained by analysis of a different reaction a higher upper limit $\Delta_{\mathrm{f}} H^{\circ}(298 \mathrm{~K})=1278 . \pm 4.6 . \mathrm{kJ} \mathrm{mol}^{-1}$. The present G3B3 calculation is $\Delta_{\mathrm{f}} H^{\circ}(298 \mathrm{~K})=1267 . \pm 8 . \mathrm{kJ} \mathrm{mol}^{-1}$. Both values are in thermal electron convention.

The Deuterated compound $\mathrm{DSi} \equiv \mathrm{SiD}$ was calculated based on the standard heat of formation of $\mathrm{HSi}=\mathrm{SiH} \Delta_{\mathrm{f}} H^{\circ}(0 \mathrm{~K})=453.4 . \pm 8 . \mathrm{kJ} \mathrm{mol}^{-1}$ to give for $\mathrm{DSi} \equiv \mathrm{SiD} \Delta_{\mathrm{f}} H^{\circ}(0 \mathrm{~K})$ $=451.96 \pm 8 . \mathrm{kJ} \mathrm{mol}^{-1}\left(\Delta_{\mathrm{f}} H^{\circ}(298 \mathrm{~K})=451.3 \pm 8 . \mathrm{kJ} \mathrm{mol}^{-1}\right)$.

\section{$\mathrm{Si}_{2} \mathrm{H}_{4}, \mathrm{Si}_{2} \mathrm{H}_{4}^{+}$: Disilene $\left.\left(\mathrm{H}_{2} \mathrm{Si}=\mathrm{SiH}\right)_{2}\right)$ and cation.}

The singlet compound disilene was calculated by Becerra and Walsh (1998) [6] with an heat of formation $\Delta_{\mathrm{f}} H^{\circ}(298 \mathrm{~K})=261 . \pm 8 . \mathrm{kJ} \mathrm{mol}^{-1}$. Ruscic and Berkovitz (1991) [35] in a photo-ionization study report $\Delta_{\mathrm{f}} H^{\circ}(298 \mathrm{~K})=275 \pm 4 . \mathrm{kJ} \mathrm{mol}^{-1}$. Ho and Melius (1990) [10] report $\Delta_{\mathrm{f}} H^{\circ}(298 \mathrm{~K})=263 . \pm 10 . \mathrm{kJ} \mathrm{mol}^{-1}$. Katzer et al. (1997) [31] calculated $\Delta_{\mathrm{f}} H^{\circ}(298 \mathrm{~K})=281.2 \mathrm{~kJ} \mathrm{~mol}^{-1}$, Broadbelt and coworkers (2004) [9] report $\Delta_{\mathrm{f}} H^{\circ}(298 \mathrm{~K})$ $=274.9 \mathrm{~kJ} \mathrm{~mol}^{-1}$ (BAC method). Sukkaew et al (2013) [16] report $\Delta_{\mathrm{f}} H^{\circ}(298 \mathrm{~K})=275.2-$ $268.3 \mathrm{~kJ} \mathrm{~mol}^{-1}$. The value of $\Delta_{\mathrm{f}} H^{\circ}(298 \mathrm{~K})=270.1 \mathrm{~kJ} / \mathrm{mol}^{-1}$ was calculated from the NASA polynomials of the Silicon Hydride Library of the chem_annotated.inp-file of the supplement of West and coworkers 2016 [18]. The present G3B3 calculation shows $\Delta_{\mathrm{f}} H^{\circ}(298 \mathrm{~K})=273.1 \pm 8 . \mathrm{kJ} \mathrm{mol}^{-1}$. 
The cation was reported by Curtiss et al (1991) [57] $\Delta_{\mathrm{f}} H^{\circ}(298 \mathrm{~K})=1066 . \mathrm{kJ} \mathrm{mol}^{-1}$, by Ruscic and Berkowitz (1991) [35] $\Delta_{\mathrm{f}} H^{\circ}(298 \mathrm{~K})=1070.6 . \pm 2.5 \mathrm{~kJ} \mathrm{~mol}^{-1}$ and the thermal electron G3B3 calculation resulted in $\Delta_{\mathrm{f}} H^{\circ}(298 \mathrm{~K})=1066 . \pm 8 . \mathrm{kJ} \mathrm{mol}^{-1}$.

\section{$\mathrm{Si}_{2} \mathrm{H}_{4}, \mathrm{Si}_{2} \mathrm{H}_{4}^{+}, \mathrm{Si}_{2} \mathrm{H}_{4}^{-}$DiSilanylidene $\mathrm{SiH}_{3}-\mathrm{SiH}$ and ions.}

Becerra and Walsh (1987) [56] have experimentally found $\Delta_{\mathrm{f}} H^{\circ}(298 \mathrm{~K})=312 . \pm 8 . \mathrm{kJ}$ $\mathrm{mol}^{-1}$ and report [6] calculated values of Pople and coworkers (1991) [57] $\Delta_{\mathrm{f}} H^{\circ}(298 \mathrm{~K})$ $=300 . \mathrm{kJ} \mathrm{mol}^{-1}$, Ho and Melius (1990)[10] $\Delta_{\mathrm{f}} H^{\circ}(298 \mathrm{~K})=313 . \pm 11 . \mathrm{kJ} \mathrm{mol}^{-1}$, Sax and Kalcher (1991) [58] $\Delta_{\mathrm{f}} H^{\circ}(298 \mathrm{~K})=317 . \mathrm{kJ} \mathrm{mol}^{-1}$, and Boatz and Gordon (1990) [59] $\Delta_{\mathrm{f}} H^{\circ}(298 \mathrm{~K})=305 . \mathrm{kJ} \mathrm{mol}^{-1}$. Katzer et al. (1997) [31] calculated $\Delta_{\mathrm{f}} H^{\circ}(298 \mathrm{~K})=318.8 \mathrm{~kJ}$ $\mathrm{mol}^{-1}$, Broadbelt and coworkers (2004) [9] calculated $\Delta_{\mathrm{f}} H^{\circ}(298 \mathrm{~K})=306.7 \mathrm{~kJ} \mathrm{~mol}^{-1}$, Sukkaew et al (2013) [16] report $\Delta_{\mathrm{f}} H^{\circ}(298 \mathrm{~K})=305.1-303.1 \mathrm{~kJ} \mathrm{~mol}^{-1}$, and Nguyen and M.C. Lin (2017) [62] using CCSD(T) method list $\Delta_{\mathrm{f}} H^{\circ}(0 \mathrm{~K})=323.8 \mathrm{~kJ} \mathrm{~mol}^{-1}$ The present G3B3 calculation lists $\Delta_{\mathrm{f}} H^{\circ}(298 \mathrm{~K})=304.2 . \pm 8 . \mathrm{kJ} \mathrm{mol}^{-1}$ and $\Delta_{\mathrm{f}} H^{\circ}(0 \mathrm{~K})=312.8 \pm 8 . \mathrm{kJ} \mathrm{mol}^{-1}$.

The cation $\mathrm{Si}_{2} \mathrm{H}_{4}+$ is calculated by Curtiss et al (1991) [57] $\Delta_{\mathrm{f}} H^{\circ}(0 \mathrm{~K})=1117.5 \mathrm{~kJ}$ $\mathrm{mol}^{-1}$ and our present thermal electron G3B3 calculation $\Delta_{\mathrm{f}} H^{\circ}(298 \mathrm{~K})=1121.2 . \pm 8 . \mathrm{kJ} \mathrm{mol}^{-1}$. The anion $\mathrm{Si}_{2} \mathrm{H}_{4}$ - is not reported to our knowledge and our thermal electron G3B3 calculation is $\Delta_{\mathrm{f}} H^{\circ}(298 \mathrm{~K})=138.97 . \pm 8 . \mathrm{kJ} \mathrm{mol}^{-1}$.

\section{$\mathrm{Si}_{2} \mathrm{H}_{5} \mathrm{Si}_{2} \mathrm{H}_{5}$ - Disilanyl and anion $\mathrm{SiH}_{3}-\mathrm{SiH}_{2} *$}

The radical was experimentally measured by Ruscic and Berkowitz (1991) [35] $\Delta_{\mathrm{f}} H^{\circ}(0 \mathrm{~K})<264.8 \mathrm{~kJ} \mathrm{~mol}^{-1}$ and a less well defined value of $247.7 \mathrm{~kJ} \mathrm{~mol}^{-1}$ is given which is nearer to the calculated value by Nguyen and M.C. Lin (2017) [62] $\Delta_{\mathrm{f}} H^{\circ}(0 \mathrm{~K})=248.9 \mathrm{~kJ}$ $\mathrm{mol}^{-1}$. The G3B3 present calculation reads $\Delta_{\mathrm{f}} H^{\circ}(298 \mathrm{~K})=227.2 \pm 8 . \mathrm{kJ} \mathrm{mol}^{-1}$ and $\Delta_{\mathrm{f}} H^{\circ}(0 \mathrm{~K})=239.9 \pm 8 . \mathrm{kJ} \mathrm{mol}^{-1}$.

To our best knowledge the anion's $\mathrm{SiH}_{3}-\mathrm{SiH}_{2}$ *- thermochemistry is not known. The thermal electron G3B3 value found is $\Delta_{\mathrm{f}} H^{\circ}(298 \mathrm{~K})=39.3 \pm 8 . \mathrm{kJ} \mathrm{mol}^{-1}$

\section{$\mathrm{Si}_{2} \mathrm{H}_{6}, \mathrm{Si}_{2} \mathrm{H}_{6}^{+}$Disilane $\mathrm{H}_{3} \mathrm{Si}-\mathrm{SiH}_{3}$ and cation.}

The Disilane is also a pyrophoric gas at STP conditions like $\mathrm{SiH}_{4} . \mathrm{H}_{3} \mathrm{Si}_{-} \mathrm{SiH}_{3}$ was listed first by Walsh in Rappoport's edited book (1989) [1] as $\Delta_{\mathrm{f}} H^{\circ}(298 \mathrm{~K})=80.3 \pm 1.5 \mathrm{~kJ}$ $\mathrm{mol}^{-1}$ and this value was used to calculate the polynomials. Katzer et al. (1997) [31] calculated $\Delta_{\mathrm{f}} H^{\circ}(298 \mathrm{~K})=79.9 \mathrm{~kJ} \mathrm{~mol}^{-1}$, Broadbelt and coworkers (2004) [9] report 
$\Delta_{\mathrm{f}} H^{\circ}(298 \mathrm{~K})=80.8 \mathrm{~kJ} \mathrm{~mol}^{-1}$; Allendorf's database (2006) (now removed from the internet) listed $\Delta_{\mathrm{f}} H^{\circ}(298 \mathrm{~K})=79.9 \pm 4.2 \mathrm{~kJ} \mathrm{~mol}^{-1}$; Hidding and Pfitzner (2006) [53] report $\Delta_{\mathrm{f}} H^{\circ}(298 \mathrm{~K})$ $=79.76 \mathrm{~kJ} \mathrm{~mol}^{-1}$, the present G3B3 (unused) calculation was $\Delta_{\mathrm{f}} H^{\circ}(298 \mathrm{~K})=73.6 \pm 8 . \mathrm{kJ} \mathrm{mol}^{-1}$; the heat of formation value for RMG calculated from NASA polynomials in the supplement of West and coworkers 2016 [18] was $\Delta_{\mathrm{f}} H^{\circ}(298 \mathrm{~K})=66.8 \mathrm{~kJ} \mathrm{~mol}^{-1}$

The cation $\mathrm{H}_{3} \mathrm{Si}_{-} \mathrm{SiH}_{3}{ }^{+}$was first reported by Lias et al (1988) [15] $\Delta_{\mathrm{f}} H^{\circ}(298 \mathrm{~K})$ $=1022 . \mathrm{kJ} \mathrm{mol}^{-1}$ then by Ruscic and Berkowitz $(1991)$ [35] $\Delta_{\mathrm{f}} H^{\circ}(298 \mathrm{~K})=1041.7 . \pm 25 . \mathrm{kJ}$ $\mathrm{mol}^{-1}$, Curtiss et al (1991) [57] $\Delta_{\mathrm{f}} H^{\circ}(298 \mathrm{~K})=1025 . \mathrm{kJ} \mathrm{mol}^{-1}$ and the present thermal electron G3B3 calculation listed $\Delta_{\mathrm{f}} H^{\circ}(298 \mathrm{~K})=1016 . \pm 8 . \mathrm{kJ} \mathrm{mol}^{-1}$.

\section{$\mathrm{Si}_{3} \mathrm{H}_{5}, \mathrm{Si}_{3} \mathrm{H}_{5}^{+}, \mathrm{Si}_{3} \mathrm{H}_{5}^{-} \quad \mathrm{H}_{2} \mathrm{Si}=\mathrm{SiH}-\mathrm{SiH}_{2}{ }^{*}$ 2-Trisilenylium and ions.}

The present G3B3 value for the radical is $\Delta_{\mathrm{f}} H^{\circ}(298 \mathrm{~K})=433.3 \pm 8 . \mathrm{kJ} \mathrm{mol}^{-1}$.

The ions enthalpy of formation is not mentioned in the literature and the thermal electron G3B3 values are $\Delta_{\mathrm{f}} H^{\circ}(298 \mathrm{~K})=1107.6 \pm 8 . \mathrm{kJ} \mathrm{mol}^{-1}$ for the cation 2-Trisilenylium and $\Delta_{\mathrm{f}} H^{\circ}(298 \mathrm{~K})=209 . \pm 8 . \mathrm{kJ} \mathrm{mol}^{-1}$ for the anion.

\section{$\mathrm{Si}_{3} \mathrm{H}_{5}, \mathrm{Si}_{3} \mathrm{H}_{5}{ }^{+}, \mathrm{Si}_{3} \mathrm{H}_{5}^{-}$Cyclotrisilane Radical (cylcotrisilanyl) and ions.}

This cyclic radical was reported by Katzer et al. (1997) [31] with $\Delta_{\mathrm{f}} H^{\circ}(298 \mathrm{~K})$ $=420.2 \mathrm{~kJ} \mathrm{~mol}^{-1}$. The present radical G3B3 calculation result in $\Delta_{\mathrm{f}} H^{\circ}(298 \mathrm{~K})=387 . \pm 8 . \mathrm{kJ}$ $\mathrm{mol}^{-1}$.

No reports were found for the cyclotrisilane radical cation $\mathrm{Si}_{3} \mathrm{H}_{5}{ }^{+}$and anion $\mathrm{Si}_{3} \mathrm{H}_{5}{ }^{-}$. The thermal electron G3B3 values are $\Delta_{\mathrm{f}} H^{\circ}(298 \mathrm{~K})=1096.1 \pm 8 . \mathrm{kJ} \mathrm{mol}^{-1}$ and $\Delta_{\mathrm{f}} H^{\circ}(298 \mathrm{~K})$ $=147.9 \pm 8 \mathrm{~kJ} \mathrm{~mol}^{-1}$ respectively.

$\mathrm{Si}_{3} \mathrm{H}_{6}, \mathrm{Si}_{3} \mathrm{H}_{6}^{+}, \mathrm{Si}_{3} \mathrm{H}_{6}^{-}$Cyclotrisilane and ions.

Heat of formation of cyclotrisilane was reported by Katzer et al. (1997) [31] as $\Delta_{\mathrm{f}} H^{\circ}(298 \mathrm{~K})=281.6 \mathrm{~kJ} \mathrm{~mol}^{-1}$ and by Broadbelt and coworkers (2004) [9] using bond additivity corrections as $\Delta_{\mathrm{f}} H^{\circ}(298 \mathrm{~K})=269.0 \mathrm{~kJ} \mathrm{~mol}^{-1}$. The heat of formation value calculated from NASA polynomials of the SiliconHydrideLibrary in the supplement of West and coworkers 2016 [18] chem_annotated.inp-file is the same as that of Katzer et al. (1997) [31. The present G3B3 calculation lists $\Delta_{\mathrm{f}} H^{\circ}(298 \mathrm{~K})=257.3 \pm 8 \mathrm{~kJ} \mathrm{~mol}^{-1}$. 
The enthalpy of formation of the ions were not reported in literature to our knowledge and our thermal electron G3B3 value lists $\Delta_{\mathrm{f}} H^{\circ}(298 \mathrm{~K})=1063.5 \pm 8 \mathrm{~kJ} \mathrm{~mol}^{-1}$ for the cation and $\Delta_{\mathrm{f}} H^{\circ}(298 \mathrm{~K})=289.2 \pm 8 \mathrm{~kJ} \mathrm{~mol}^{-1}$ for the anion.

\section{$n-\mathrm{Si}_{3} \mathrm{H}_{7} \quad n-\mathrm{Si}_{3} \mathrm{H}_{7}+n-\mathrm{Si}_{3} \mathrm{H}_{7^{-}}$Trisilan-1-yl and ions $\mathrm{SiH}_{3}-\mathrm{SiH}_{2}-\mathrm{SiH}_{2}{ }^{*}$}

Katzer et al. (1997) [31] calculated $\Delta_{\mathrm{f}} H^{\circ}(298 \mathrm{~K})=274.8 \mathrm{~kJ} \mathrm{~mol}^{-1}$, Ragunath and M.C. Lin (2013) [64] report $\Delta_{\mathrm{f}} H^{\circ}(0 \mathrm{~K})=287.4 \pm 4.2 \mathrm{~kJ} \mathrm{~mol}^{-1}$. Nguyen and M.C. Lin (2017) [62] using $\operatorname{CCSD}(\mathrm{T})$ method list $\Delta_{\mathrm{f}} H^{\circ}(0 \mathrm{~K})=288,7 \mathrm{~kJ} \mathrm{~mol}^{-1}$. The G3B3 value is $\Delta_{\mathrm{f}} H^{\circ}(298 \mathrm{~K})=262.4 \pm 8 . \mathrm{kJ} \mathrm{mol}^{-1},\left(\Delta_{\mathrm{f}} H^{\circ}(0 \mathrm{~K})=280.1 \pm 8 . \mathrm{kJ} \mathrm{mol}^{-1}\right)$.

The cation $\mathrm{SiH}_{3}-\mathrm{SiH}_{2}-\mathrm{SiH}_{2}{ }^{*}+$ is not mentioned in the literature and has no CAS number. The thermal electron G3B3 value found is $\Delta_{\mathrm{f}} H^{\circ}(298 \mathrm{~K})=965.8 \pm 8 . \mathrm{kJ} \mathrm{mol}^{-1}$. The anion $\mathrm{SiH}_{3}-\mathrm{SiH}_{2}-\mathrm{SiH}_{2}{ }^{*}$ - has a G3B3 thermal electron value of $\Delta_{\mathrm{f}} H^{\circ}(298 \mathrm{~K})=56.2 \pm 8 . \mathrm{kJ}$ $\mathrm{mol}^{-1}$.

\section{$i-\mathrm{Si}_{3} \mathrm{H}_{7} i-\mathrm{Si}_{3} \mathrm{H}_{7}+i-\mathrm{Si}_{3} \mathrm{H}_{7^{-}}$Disilanyl-1-silyl (Trisilan-2-yl) $\mathrm{SiH}_{3}-\mathrm{SiH}^{*}-\mathrm{SiH}_{3}$ and ions.}

The $i s o-\mathrm{Si}_{3} \mathrm{H}_{7}$ radical is listed by Katzer et al. (1997) [31] $\Delta_{\mathrm{f}} H^{\circ}(298 \mathrm{~K})=268.2 \mathrm{~kJ}$ $\mathrm{mol}^{-1}$. Ragunath and M.C. Lin (2013) [64] report $\Delta_{\mathrm{f}} H^{\circ}(0 \mathrm{~K})=279.9 \pm 4.2 \mathrm{~kJ} \mathrm{~mol}^{-1}$. Our G3B3 value is $\Delta_{\mathrm{f}} H^{\circ}(298 \mathrm{~K})=251.7 \pm 8 . \mathrm{kJ} \mathrm{mol}^{-1},\left(\Delta_{\mathrm{f}} H^{\circ}(0 \mathrm{~K})=269.9 \pm 8 . \mathrm{kJ} \mathrm{mol}^{-1}\right)$.

The ions of the $i s o-\mathrm{Si}_{3} \mathrm{H}_{7}$ radical were not reported and the thermal electron G3B3 values calculated are $\Delta_{\mathrm{f}} H^{\circ}(298 \mathrm{~K})=977.6 \pm 8 . \mathrm{kJ} \mathrm{mol}^{-1}$ and $\Delta_{\mathrm{f}} H^{\circ}(298 \mathrm{~K})=28.8 \pm 8 . \mathrm{kJ} \mathrm{mol}^{-1}$ for the cation $\mathrm{SiH}_{3}-\mathrm{SiH}^{*}-\mathrm{SiH}_{3}+$ and anion $\mathrm{SiH}_{3}-\mathrm{SiH}^{*}-\mathrm{SiH}_{3}-$, respectively.

\section{$\mathrm{Si}_{3} \mathrm{H}_{8}, \mathrm{Si}_{3} \mathrm{H}_{8}^{-}$Trisilane $\mathrm{H}_{3} \mathrm{Si}_{-} \mathrm{SiH}_{2}-\mathrm{SiH}_{3}$ and anion .}

Trisilane was listed by Ho et al (1986) [11] $\Delta_{\mathrm{f}} H^{\circ}(298 \mathrm{~K})=118.4 \pm 12 . \mathrm{kJ} \mathrm{mol}^{-1}$; by Bercerra and Walsh (1998) [6] as $\Delta_{\mathrm{f}} H^{\circ}(298 \mathrm{~K})=121 . \pm 4.4 \mathrm{~kJ} \mathrm{~mol}^{-1}$. Katzer et al. (1997) [31] calculated $\Delta_{\mathrm{f}} H^{\circ}(298 \mathrm{~K})=120.6 \mathrm{~kJ} \mathrm{~mol}^{-1}$, Ochterski et al. (1995) [7] report $\Delta_{\mathrm{f}} H^{\circ}(298 \mathrm{~K})$ $=120.5 \mathrm{~kJ} \mathrm{~mol}^{-1}$. Allendorf et al. (1992) [30] report $\Delta_{\mathrm{f}} H^{\circ}(298 \mathrm{~K})=120.9 \mathrm{~kJ} \mathrm{~mol}^{-1}$. Hidding and Pfitzner (2006) [53] list $\Delta_{\mathrm{f}} H^{\circ}(298 \mathrm{~K})=120.95 \mathrm{~kJ} \mathrm{~mol}^{-1}$. Sukkaew et al. (2014) [16] $\Delta_{\mathrm{f}} H^{\circ}(298 \mathrm{~K})=111.5 \mathrm{~kJ} \mathrm{~mol}^{-1}$ using the $\mathrm{G} 4$ method. Heat of formation of $\Delta_{\mathrm{f}} H^{\circ}(298 \mathrm{~K})=126.4$ $\mathrm{kJ} \mathrm{mol}^{-1}$, is calculated from NASA polynomials in the supplement of West and coworker (2016) [18], which uses group additivity values of silicon species. The present G3B3 calculation is $\Delta_{\mathrm{f}} H^{\circ}(298 \mathrm{~K})=109.2 \pm 8 . \mathrm{kJ} \mathrm{mol}^{-1}$ in very good agreement with Sukkaew et al. [16]. 
The anion is not reported in the literature and the thermal electron value obtained from use of G3B3 method result in $\Delta_{\mathrm{f}} H^{\circ}(298 \mathrm{~K})=122.12 \pm 8 . \mathrm{kJ} \mathrm{mol}^{-1}$. No CAS number was found for the anion.

\section{$\mathrm{Si}_{4} \mathrm{H}_{7}, \mathrm{Si}_{4} \mathrm{H}_{7}^{+}, \mathrm{Si}_{4} \mathrm{H}_{7}^{-}$Cyclotetrasilane radical (Cyclotetrasilanyl) and ions.}

The heat of formation of this cyclic radical was calculated by Katzer et al. (1997) [31] as $\Delta_{\mathrm{f}} H^{\circ}(298 \mathrm{~K})=372.8$ and $369.5 \mathrm{~kJ} \mathrm{~mol}^{-1}$, depending on the used basis set in their quantum chemical calculations. The present G3B3 result is $\Delta_{\mathrm{f}} H^{\circ}(298 \mathrm{~K})=339.2 \pm 12$. kJ $\mathrm{mol}^{-1}$.

No quotations for the enthalpy of formation of the ions was found in the literature, and the thermal electron G3B3 results are $\Delta_{\mathrm{f}} H^{\circ}(298 \mathrm{~K})=1026.2 \pm 12 . \mathrm{kJ} \mathrm{mol}^{-1}$ for the cation and $\Delta_{\mathrm{f}} H^{\circ}(298 \mathrm{~K})=108.8 \pm 12 . \mathrm{kJ} \mathrm{mol}^{-1}$ for the anion.

\section{$\mathrm{Si}_{4} \mathrm{H}_{8}, \mathrm{Si}_{4} \mathrm{H}_{8}{ }^{+}$Cyclotetrasilane and cation.}

Heat of formation of cyclotetratilane was reported first by Katzer et al (1997) [31] $\Delta_{\mathrm{f}} H^{\circ}(298 \mathrm{~K})=231.4 \mathrm{~kJ} \mathrm{~mol}^{-1}$; Broadbelt and coworkers (2004) [9] report $\Delta_{\mathrm{f}} H^{\circ}(298 \mathrm{~K})$ $=215.9 \mathrm{~kJ} \mathrm{~mol}^{-1}$ by the BAC method and the present G3B3 result is $\Delta_{\mathrm{f}} H^{\circ}(298 \mathrm{~K})$ $=201.06 \pm 12 . \mathrm{kJ} \mathrm{mol}^{-1}$. West and coworkers 2016 [18] provide NASA polynomials in the chem_annotated.inp-file of the supplement, which result in $\Delta_{\mathrm{f}} H^{\circ}(298 \mathrm{~K})=255.4 \mathrm{~kJ} \mathrm{~mol}^{-1}$.

No calculation of the cation was found in the literature and its thermal electron G3B3 calculation lists $\Delta_{\mathrm{f}} H^{\circ}(298 \mathrm{~K})=1062.1 \pm 12 . \mathrm{kJ} \mathrm{mol}^{-1}$. No CAS number is available.

\section{$n-\mathrm{Si}_{4} \mathrm{H}_{9} n-\mathrm{Si}_{4} \mathrm{H}_{9}+n-\mathrm{Si}_{4} \mathrm{H}_{9-}$ Tetrasilanyl and ions $\mathrm{SiH}_{3}-\mathrm{SiH}_{2}-\mathrm{SiH}_{2}-\mathrm{SiH}_{2}{ }^{*}$}

The enthalpy of formation of tetrasilane-1-yl was reported first by Katzer et al (1997) [31] $\Delta_{\mathrm{f}} H^{\circ}(298 \mathrm{~K})=312.8 \mathrm{~kJ} \mathrm{~mol}^{-1}$; The G3B3 value calculated is $\Delta_{\mathrm{f}} H^{\circ}(298 \mathrm{~K})$ $=293.8 \pm 12 . \mathrm{kJ} \mathrm{mol}^{-1}$.

The cation $\mathrm{SiH}_{3}-\mathrm{SiH}_{2}-\mathrm{SiH}_{2}-\mathrm{SiH}_{2} *+$ is not reported in the literature and has no CAS number. The thermal electron G3B3 value calculated for the cation is $\Delta_{\mathrm{f}} H^{\circ}(298 \mathrm{~K})$ $=940 . \pm 12 . \mathrm{kJ} \mathrm{mol}^{-1}$. The anion $\mathrm{SiH}_{3}-\mathrm{SiH}_{2}-\mathrm{SiH}_{2}-\mathrm{SiH}_{2}{ }^{*}$ - got a G3B3 value of $\Delta_{\mathrm{f}} H^{\circ}(298 \mathrm{~K})$ $=77.12 \pm 12 . \mathrm{kJ} \mathrm{mol}^{-1}$. 


\section{$i-\mathrm{Si}_{4} \mathrm{H}_{9} i-\mathrm{Si}_{4} \mathrm{H}_{9}+i-\mathrm{Si}_{4} \mathrm{H}_{9}-$ Tetrasilenyl-1-silyl and ions $\mathrm{SiH}_{3}-\mathrm{SiH}^{*}-\mathrm{SiH}_{2}-\mathrm{SiH}_{3}$}

The heat of formation of Tetrasylenyl-1-silyl (Tetrasilane-2-yl) was reported by Katzer et al (1997) [31] $\Delta_{\mathrm{f}} H^{\circ}(298 \mathrm{~K})=306.2 \mathrm{~kJ} \mathrm{~mol}^{-1}$; The G3B3 value found is $\Delta_{\mathrm{f}} H^{\circ}(298 \mathrm{~K})=285.9 \pm 12 . \mathrm{kJ} \mathrm{mol}^{-1}$.

The cation $\mathrm{SiH}_{3}-\mathrm{SiH}^{*}-\mathrm{SiH}_{2}-\mathrm{SiH}_{3}+$ has no CAS number. The thermal electron G3B3 value found is $\Delta_{\mathrm{f}} H^{\circ}(298 \mathrm{~K})=984.9 \pm 12 . \mathrm{kJ} \mathrm{mol}^{-1}$. The anion $\mathrm{SiH}_{3}-\mathrm{SiH}^{*}-\mathrm{SiH}_{2}-\mathrm{SiH}_{3}$ - got a G3B3 value of $\Delta_{\mathrm{f}} H^{\circ}(298 \mathrm{~K})=47.9 \pm 12 . \mathrm{kJ} \mathrm{mol}^{-1}$.

\section{$\mathrm{Si}_{4} \mathrm{H}_{9} \mathrm{Si}_{4} \mathrm{H}_{9}+\mathrm{Si}_{4} \mathrm{H}_{9}$ - Trisilanyl-2-silyl and ions $\left(\mathrm{SiH}_{3}\right)_{2}-\mathrm{SiH}-\mathrm{SiH}_{2} *$}

The heat of formation of Trisilanyl-2-silyl (2-silyltrisilan-1-yl) was reported by Katzer et al (1997) [31] $\Delta_{\mathrm{f}} H^{\circ}(298 \mathrm{~K})=312.1 \mathrm{~kJ} \mathrm{~mol}^{-1}$; The G3B3 value found is $\Delta_{\mathrm{f}} H^{\circ}(298 \mathrm{~K})=287.5 \pm 12 . \mathrm{kJ} \mathrm{mol}^{-1}$.

The cation $\left(\mathrm{SiH}_{3}\right)_{2}-\mathrm{SiH}_{-} \mathrm{SiH}_{2}{ }^{*}$ has no CAS number. The thermal electron G3B3 value calculated is $\Delta_{\mathrm{f}} H^{\circ}(298 \mathrm{~K})=993.9 \pm 12 . \mathrm{kJ} \mathrm{mol}^{-1}$. The anion $\left(\mathrm{SiH}_{3}\right)_{2}-\mathrm{SiH}_{-}-\mathrm{SiH}_{2}{ }^{*}$ - got a G3B3 value of $\Delta_{\mathrm{f}} H^{\circ}(298 \mathrm{~K})=66.3 \pm 12 . \mathrm{kJ} \mathrm{mol}^{-1}$.

\section{$\mathrm{Si}_{4} \mathrm{H}_{9} \mathrm{Si}_{4} \mathrm{H}_{9-}$ - Disilanyl-1,1-disilyl and anion $\left(\mathrm{SiH}_{3}\right)_{3}-\mathrm{Si}^{*}$}

The G3B3 value calculated was $\Delta_{\mathrm{f}} H^{\circ}(298 \mathrm{~K})=270.6 \pm 12 . \mathrm{kJ} \mathrm{mol}^{-1}$.

The thermal electron G3B3 value of the anion Trisilane-2-silyl $\left(\mathrm{SiH}_{3}\right)_{3}-\mathrm{Si}^{*}$ - is $\Delta_{\mathrm{f}} H^{\circ}(298 \mathrm{~K})=17.85 \pm 12 . \mathrm{kJ} \mathrm{mol}^{-1}$.

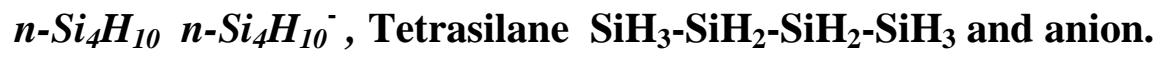

The heat of formation of Tetrasilane is reported by Katzer et al (1997) [31] as $\Delta_{\mathrm{f}} H^{\circ}(298 \mathrm{~K})=160.3 \mathrm{~kJ} \mathrm{~mol}^{-1}$, by Broadbelt and coworkers (2004) [9] as $\Delta_{\mathrm{f}} H^{\circ}(298 \mathrm{~K})=147.7$ and $158.6 \mathrm{~kJ} \mathrm{~mol}^{-1}$ for using atomization energy and bond additivity corrections, respectively, and by Hidding \& Pfitzner (2006) [53] as $\Delta_{\mathrm{f}} H^{\circ}(298 \mathrm{~K})=160.64 \mathrm{~kJ} \mathrm{~mol}^{-1}$. The present G3B3 calculation lists $\Delta_{\mathrm{f}} H^{\circ}(298 \mathrm{~K})=142.86 \pm 12 . \mathrm{kJ} \mathrm{mol}^{-1}$.

The anion appears to be calculated for the first time and the thermal electron G3B3 results in $\Delta_{\mathrm{f}} H^{\circ}(298 \mathrm{~K})=128.33 \pm 12 . \mathrm{kJ} \mathrm{mol}^{-1}$. 
$\mathrm{Si}_{5} \mathrm{H}_{9}, \mathrm{Si}_{5} \mathrm{H}_{9}{ }^{+}, \mathrm{Si}_{5} \mathrm{H}_{9}{ }^{-}$Cyclopentasilane radical [-SiH $2-\mathrm{SiH}_{2}-\mathrm{SiH}_{2}-\mathrm{SiH}_{2}-\mathrm{SiH}^{*}$-] and ions.

This radical is reported by Katzer et al (1997) [31] as $\Delta_{\mathrm{f}} H^{\circ}(298 \mathrm{~K})=365.6 \mathrm{~kJ} \mathrm{~mol}^{-1}$. The present G3B3 result is $\Delta_{\mathrm{f}} H^{\circ}(298 \mathrm{~K})=327.4 \pm 15 . \mathrm{kJ} \mathrm{mol}^{-1}$.

The thermochemistry of the cation and anion was not published to our knowledge and the thermal electron G3B3 calculation is $\Delta_{\mathrm{f}} H^{\circ}(298 \mathrm{~K})=1027.4 \pm 15 . \mathrm{kJ} \mathrm{mol}^{-1}$ and $\Delta_{\mathrm{f}} H^{\circ}(298 \mathrm{~K})=79.8 \pm 15 . \mathrm{kJ} \mathrm{mol}^{-1}$ respectively. The cation has no CAS number.

\section{$\mathrm{Si}_{5} \mathrm{H}_{10}, \mathrm{Si}_{5} \mathrm{H}_{10}{ }^{+} \mathrm{Cyclopentasilane}\left[-\mathrm{SiH}_{2}-\mathrm{SiH}_{2}-\mathrm{SiH}_{2}-\mathrm{SiH}_{2}-\mathrm{SiH}_{2}-\right]$ and cation.}

Katzer et al. (1997) [31] reported for cyclopentasilane a heat of formation value $\Delta_{\mathrm{f}} H^{\circ}(298 \mathrm{~K})=221.4 \mathrm{~kJ} \mathrm{~mol}^{-1}$. Swihart and Girshick (1999) [32] report $\Delta_{\mathrm{f}} H^{\circ}(298 \mathrm{~K})=$ $220.08 \mathrm{~kJ} \mathrm{~mol}^{-1}$. Broadbelt and coworkers (2004) [9] reported $\Delta_{\mathrm{f}} H^{\circ}(298 \mathrm{~K})=193.7 \mathrm{~kJ}$ $\mathrm{mol}^{-1}$ for using atomization energies and $207.9 \mathrm{~kJ} \mathrm{~mol}^{-1}$ for using bond additivity corrections. The present G3B3 calculation result in $\Delta_{\mathrm{f}} H^{\circ}(298 \mathrm{~K})=189.4 \pm 15$. $\mathrm{kJ} \mathrm{mol}^{-1}$.

The thermochemistry of the cation $\mathrm{Si}_{5} \mathrm{H}_{10}{ }^{+}$was not listed in the literature and the thermal electron value calculated is $\Delta_{\mathrm{f}} H^{\circ}(298 \mathrm{~K})=1058.6 \pm 15 . \mathrm{kJ} \mathrm{mol}^{-1}$.

\section{$\mathrm{Si}_{5} \mathrm{H}_{12}, \mathrm{Si}_{5} \mathrm{H}_{12}{ }^{-} \mathrm{n}-\mathrm{Pentasilane} \mathrm{SiH}_{3}-\mathrm{SiH}_{2}-\mathrm{SiH}_{2}-\mathrm{SiH}_{2}-\mathrm{SiH}_{3}$ and anion.}

Heat of formation of linear pentasilane was calculated by Katzer et al. (1997) [31] as $\Delta_{\mathrm{f}} H^{\circ}(298 \mathrm{~K})=199.7 \mathrm{~kJ} \mathrm{~mol}^{-1}$, by Broadbelt and coworkers $(2004)$ [9] as $\Delta_{\mathrm{f}} H^{\circ}(298 \mathrm{~K})=$ $182.4 \mathrm{~kJ} \mathrm{~mol}^{-1}$ using atomization energies and as $195.8 \mathrm{~kJ} \mathrm{~mol}^{-1}$ using bond additivity corrections based on G3B3 calculations, and by Hidding and Pfitzer (2006) [53] $\Delta_{\mathrm{f}} H^{\circ}(298 \mathrm{~K})=200.60 \mathrm{~kJ} \mathrm{~mol}^{-1}$. The present G3B3 calculation results in $\Delta_{\mathrm{f}} H^{\circ}(298 \mathrm{~K})=$ $177.37 \pm 15 . \mathrm{kJ} \mathrm{mol}^{-1}$.

The anion $\mathrm{Si}_{5} \mathrm{H}_{12}{ }^{-}$has not been reported and the present $\mathrm{G} 3 \mathrm{~B} 3$ thermal calculation reads $\Delta_{\mathrm{f}} H^{\circ}(298 \mathrm{~K})=144.5 \pm 15 . \mathrm{kJ} \mathrm{mol}^{-1}$.

\section{$\mathrm{Si}_{6} \mathrm{H}_{11}, \mathrm{Si}_{6} \mathrm{H}_{11}{ }^{+}, \mathrm{Si}_{6} \mathrm{H}_{11}{ }^{-} \mathrm{Cyclohexasilane}$ radical [-SiH${ }_{2}-\mathrm{SiH}_{2}-\mathrm{SiH}_{2}-\mathrm{SiH}_{2}-\mathrm{SiH}_{2}-\mathrm{SiH}^{*}$ ] (Cyclohexasilyl) and ions.}

The present G3B3 calculation gives $\Delta_{\mathrm{f}} H^{\circ}(298 \mathrm{~K})=351.6 \pm 20 . \mathrm{kJ} \mathrm{mol}^{-1}$ for cyclohexasilyl. 
The ions were not reported in the literature and the cation does not have a CAS number. The thermal electron G3B3 calculation results in $\Delta_{\mathrm{f}} H^{\circ}(298 \mathrm{~K})=1039.4 \pm 20 . \mathrm{kJ}$ $\mathrm{mol}^{-1}$ and $\Delta_{\mathrm{f}} H^{\circ}(298 \mathrm{~K})=99.1 \pm 20 . \mathrm{kJ} \mathrm{mol}^{-1}$ for cation and anion respectively.

\section{$\mathrm{Si}_{6} \mathrm{H}_{12}, \mathrm{Si}_{6} \mathrm{H}_{12}{ }^{+}, \mathrm{Si}_{6} \mathrm{H}_{12}{ }^{-}$Cyclohexasilane [- $\mathrm{SiH}_{2}-\mathrm{SiH}_{2}-\mathrm{SiH}_{2}-\mathrm{SiH}_{2}-\mathrm{SiH}_{2}-\mathrm{SiH}_{2}$-] and ions.}

Katzer et al. (1997) [31] reports $\Delta_{\mathrm{f}} H^{\circ}(298 \mathrm{~K})=227.6 \mathrm{~kJ} \mathrm{~mol}^{-1}$; Broadbelt and coworkers (2004) [9] report $\Delta_{\mathrm{f}} H^{\circ}(298 \mathrm{~K})=211.3 \mathrm{~kJ} \mathrm{~mol}^{-1}$ using atomization energies and $\Delta_{\mathrm{f}} H^{\circ}(298 \mathrm{~K})=227.6 \mathrm{~kJ} \mathrm{~mol}^{-1}$ by using bond additivity corrections, and the present G3B3 result is $\Delta_{\mathrm{f}} H^{\circ}(298 \mathrm{~K})=212.5 \pm 20 . \mathrm{kJ} \mathrm{mol}^{-1}$.

The cation and anion were not mentioned in the literature, the anion has no CAS number, and the present thermal electron G3B3 values are $\Delta_{\mathrm{f}} H^{\circ}(298 \mathrm{~K})=1074.2 \pm 20 . \mathrm{kJ}$ $\mathrm{mol}^{-1}$ and $\Delta_{\mathrm{f}} H^{\circ}(298 \mathrm{~K})=204.2 \pm 20 . \mathrm{kJ} \mathrm{mol}^{-1}$ respectively.

\section{Results for organic carbon containing silicon species:}

\section{$\mathrm{CH}_{2} \mathrm{Si}, \mathrm{CH}_{2} \mathrm{Si}^{-}$Silynemethylidyne $\mathrm{HC} \equiv \mathrm{SiH}$ and anion.}

The enthalpy of formation of this acetylene type compound was not found in literature, although its structure was calculated [54]. Our G3B3 calculation shows $\Delta_{\mathrm{f}} H^{\circ}(298 \mathrm{~K})=452.4 \pm 8 . \mathrm{kJ} \mathrm{mol}^{-1}$.

The thermal electron G3B3 value for the anion $\mathrm{HC} \equiv \mathrm{SiH}^{-}$is $\Delta_{\mathrm{f}} H^{\circ}(298 \mathrm{~K})=338.6 \pm 8$. $\mathrm{kJ} \mathrm{mol}^{-1}$.

\section{$\mathrm{CH}_{4} \mathrm{Si}, \mathrm{CH}_{4} \mathrm{Si}^{+}, \mathrm{CH}_{4} \mathrm{Si}^{-}$Methylenesilene $\mathrm{H}_{2} \mathrm{C}=\mathrm{SiH}_{2}$ and ions.}

This compound was published in the Chemkin thermochemical database (1982) [13] and by Allendorf et al. (1992) [30] $\Delta_{\mathrm{f}} H^{\circ}(298 \mathrm{~K})=170.3 \mathrm{~kJ} \mathrm{~mol}^{-1}$. Wiberg and coworkers (1995) [7] report for calculations with CBS-Q method $\Delta_{\mathrm{f}} H^{\circ}(298 \mathrm{~K})=193.7 \mathrm{~kJ}$ $\mathrm{mol}^{-1}$. Becerra and Walsh (1998) [6] reported $\Delta_{\mathrm{f}} H^{\circ}(298 \mathrm{~K})=187 . \pm 6 . \mathrm{kJ} \mathrm{mol}^{-1}$. Sukkaew et al. (2014) [16] report for calculation results using G4 and G4(MP2) method $\Delta_{\mathrm{f}} H^{\circ}(298 \mathrm{~K})=$ 188.9 and $184.3 \mathrm{~kJ} \mathrm{~mol}^{-1}$ respectively. The present G3B3 calculation reports $\Delta_{\mathrm{f}} H^{\circ}(298 \mathrm{~K})=$ $187.3 \pm 8 . \mathrm{kJ} \mathrm{mol}^{-1}$.

The ions were not reported in the literature and the thermal electron G3B3 value obtained was $\Delta_{\mathrm{f}} H^{\circ}(298 \mathrm{~K})=1051.4 \pm 8 . \mathrm{kJ} \mathrm{mol}^{-1}$ for the cation $\mathrm{H}_{2} \mathrm{C}=\mathrm{SiH}_{2}{ }^{+}$and $\Delta_{\mathrm{f}} H^{\circ}(298 \mathrm{~K})$ $=177.4 \pm 8 . \mathrm{kJ} \mathrm{mol}^{-1}$ for the anion $\mathrm{H}_{2} \mathrm{C}=\mathrm{SiH}_{2}^{-}$. 


\section{$\mathrm{CH}_{5} \mathrm{Si}, \mathrm{CH}_{5} \mathrm{Si}^{+} \mathrm{CH}_{5} \mathrm{Si}^{-}$Methylsilyl radical $\left(\mathrm{H}_{3} \mathrm{C}_{-} \mathrm{SiH}_{2}{ }^{*}\right)$ and ions.}

The heat of formation of the radical methylsilyl is reported by Wiberg and coworkers (1995) [7] as $\Delta_{\mathrm{f}} H^{\circ}(298 \mathrm{~K})=149.4 \pm 8 . \mathrm{kJ} \mathrm{mol}^{-1}$. Allendorf et al. (1992) [30] report $\Delta_{\mathrm{f}} H^{\circ}(298 \mathrm{~K})=139.1 \mathrm{~kJ} \mathrm{~mol}^{-1}$; Becerra and Walsh $(1998)$ [6] report $\Delta_{\mathrm{f}} H^{\circ}(298 \mathrm{~K})=$ 141.4 $\pm 6 . \mathrm{kJ} \mathrm{mol}^{-1}$. Sukkaew et al. report (2014) [16] for calculations with G4 and G4MP2 method $\Delta_{\mathrm{f}} H^{\circ}(298 \mathrm{~K})=142.1$ and $138.2 \mathrm{~kJ} \mathrm{~mol}^{-1}$ respectively. The present G3B3 calculation resulted in $\Delta_{\mathrm{f}} H^{\circ}(298 \mathrm{~K})=141.9 \pm 8 . \mathrm{kJ} \mathrm{mol}^{-1}$.

The cation $\mathrm{CH}_{3} \mathrm{SiH}_{2}{ }^{*+}$ and anion $\mathrm{CH}_{3} \mathrm{SiH}_{2}{ }^{{ }^{*}}$ are presented here for the first time and their thermal electron G3B3 calculations resulted in $\Delta_{\mathrm{f}} H^{\circ}(298 \mathrm{~K})=864.9 \pm 8 . \mathrm{kJ} \mathrm{mol}^{-1}$ and $\Delta_{\mathrm{f}} H^{\circ}(298 \mathrm{~K})=22.4 \pm 8 . \mathrm{kJ} \mathrm{mol}^{-1}$.

\section{$\mathrm{CH}_{6} \mathrm{Si}, \mathrm{CH}_{6} \mathrm{Si}^{+}$Methylsilane $\mathrm{H}_{3} \mathrm{C}-\mathrm{SiH}_{3}$ and cation.}

Heat of formation of methylsilane is reported by Becerra and Walsh (1998) [6] as $\Delta_{\mathrm{f}} H^{\circ}(298 \mathrm{~K})=-29.1 \pm 4 . \mathrm{kJ} \mathrm{mol}^{-1}$. Wiberg and coworkers $(1995)$ [7] report $\Delta_{\mathrm{f}} H^{\circ}(298 \mathrm{~K})=$ $-25.1 \mathrm{~kJ} \mathrm{~mol}^{-1}$. Sukkaew et al. (2014) [16] report $\Delta_{\mathrm{f}} H^{\circ}(298 \mathrm{~K})=-26.6 \mathrm{~kJ} \mathrm{~mol}^{-1}$ and the present G3B3 calculation results in $\Delta_{\mathrm{f}} H^{\circ}(298 \mathrm{~K})=-27.4 \pm 8 . \mathrm{kJ} \mathrm{mol}^{-1}$.

The heat of formation of the cation $\mathrm{CH}_{3} \mathrm{SiH}_{3}{ }^{+}$was reported by Lias et al. (1988) [15] as $\Delta_{\mathrm{f}} H^{\circ}(298 \mathrm{~K})=1009 . \mathrm{kJ} \mathrm{mol}^{-1}$ and the present G3B3 lists $\Delta_{\mathrm{f}} H^{\circ}(298 \mathrm{~K})=1001.1 \pm 8 . \mathrm{kJ}$ $\mathrm{mol}^{-1}$, both are thermal electron values.

\section{$\mathrm{CH}_{6} \mathrm{Si}_{2}, \mathrm{CH}_{6} \mathrm{Si}_{2}{ }^{+}, \mathrm{CH}_{6} \mathrm{Si}_{2}^{-}$1-Methyldisilydenyl $\mathrm{H}_{3} \mathrm{C}-\mathrm{SiH}_{2} \mathrm{SiH}$ and ions}

This radical is reported by Sukkaew et al. (2014) [16] with $\Delta_{\mathrm{f}} H^{\circ}(298 \mathrm{~K})=248.4$ and $247.7 \mathrm{~kJ} \mathrm{~mol}^{-1}$ using G4 and G4MP2 methods. An erroneous value of $\Delta_{\mathrm{f}} H^{\circ}(298 \mathrm{~K})=-42.3$ $\mathrm{kJ} \mathrm{mol}^{-1}$ is in the NASA polynomials of the thermochemical data of the Chemkin database [13] The present G3B3 value is $\Delta_{\mathrm{f}} H^{\circ}(298 \mathrm{~K})=247.9 \pm 8 . \mathrm{kJ} \mathrm{mol}^{-1}$, like the Sukkaew et al. [16] results.

The cation $\mathrm{H}_{3} \mathrm{CSiH}_{2} \mathrm{SiH}^{+}$and anion $\mathrm{H}_{3} \mathrm{CSiH}_{2} \mathrm{SiH}^{-}$were not reported and the anion has no CAS number. Their thermal electron G3B3 calculation results in $\Delta_{\mathrm{f}} H^{\circ}(298 \mathrm{~K})=$ $1038.3 \pm 8 . \mathrm{kJ} \mathrm{mol}^{-1}$ and $\Delta_{\mathrm{f}} H^{\circ}(298 \mathrm{~K})=82.4 \pm 8 . \mathrm{kJ} \mathrm{mol}^{-1}$ respectively.

\section{$\mathrm{C}_{2} \mathrm{H}_{4} \mathrm{Si}, \mathrm{C}_{2} \mathrm{H}_{4} \mathrm{Si}^{+}, \mathrm{C}_{2} \mathrm{H}_{4} \mathrm{Si}^{-}$, Ethylidenesilylene $\mathrm{H}_{2} \mathrm{C}=\mathrm{CH}-\mathrm{SiH}$ and ions.}

The heat of formation of ethylidenesilylene obtained from G3B3 calculation results in $\Delta_{\mathrm{f}} H^{\circ}(298 \mathrm{~K})=307.4 \pm 8 . \mathrm{kJ} \mathrm{mol}^{-1}$. The same value is given by Allendorf et al. [12], and 
Sukkaev et al. (2014) [16] reports $\Delta_{\mathrm{f}} H^{\circ}(298 \mathrm{~K})=309.3$ and $306.8 \mathrm{~kJ} \mathrm{~mol}^{-1}$ using G4 and G4MP2 methods.

The heat of formation of the cation $\mathrm{CH}_{2}=\mathrm{CH}-\mathrm{SiH}^{+}$and anion $\mathrm{CH}_{2}=\mathrm{CH}-\mathrm{SiH}^{-}$ obtained in thermal electron convention from G3B3 calculations are $\Delta_{\mathrm{f}} H^{\circ}(298 \mathrm{~K})=$ $1122.6 \pm 8 . \mathrm{kJ} \mathrm{mol}^{-1}$ and $\Delta_{\mathrm{f}} H^{\circ}(298 \mathrm{~K})=200.9 \pm 8 . \mathrm{kJ} \mathrm{mol}^{-1}$ respectively. The anion has no CAS number

\section{$\mathrm{C}_{2} \mathrm{H}_{6} \mathrm{Si}, \mathrm{C}_{2} \mathrm{H}_{6} \mathrm{Si}^{+}, \mathrm{C}_{2} \mathrm{H}_{6} \mathrm{Si}^{-}$Vinylsilane $\mathrm{H}_{2} \mathrm{C}=\mathrm{CH}-\mathrm{SiH}_{3}$ and ions.}

Heat of formation of vinylsilane was estimated by Lias et al. (1988) [15] $\Delta_{\mathrm{f}} H^{\circ}(298 \mathrm{~K})=$ $4.2 \pm 12.5$. $\mathrm{kJ} \mathrm{mol}^{-1}$; by Allendorf et al. (1992) [30] $\Delta_{\mathrm{f}} H^{\circ}(298 \mathrm{~K})=86.6 \mathrm{~kJ} \mathrm{~mol}^{-1}$; reported by Sukkaew et al. (2014) [16] $\Delta_{\mathrm{f}} H^{\circ}(298 \mathrm{~K})=88.4$ and $90.2 \mathrm{~kJ} \mathrm{~mol}^{-1}$ using G4 and G4MP2 methods. The present G3B3 result is $\Delta_{\mathrm{f}} H^{\circ}(298 \mathrm{~K})=90.2 \pm 8 . \mathrm{kJ} \mathrm{mol}^{-1}$.

The cation is estimated by Lias et al. (1988) [15] in thermal electron convention as $\Delta_{\mathrm{f}} H^{\circ}(298 \mathrm{~K})=984 . \mathrm{kJ} \mathrm{mol}^{-1}$ and the present thermal electron G3B3 value is $\Delta_{\mathrm{f}} H^{\circ}(298 \mathrm{~K})=$ $1062.6 \pm 8 . \mathrm{kJ} \mathrm{mol}^{-1}$. The anion is not reported and has no CAS number. The thermal electron G3B3 value is $\Delta_{\mathrm{f}} H^{\circ}(298 \mathrm{~K})=165.2 \pm 8 . \mathrm{kJ} \mathrm{mol}^{-1}$.

\section{$\mathrm{C}_{2} \mathrm{H}_{6} \mathrm{Si}, \mathrm{C}_{2} \mathrm{H}_{6} \mathrm{Si}^{+}, \mathrm{C}_{2} \mathrm{H}_{6} \mathrm{Si}^{-}$Methylmethylenesilane $\mathrm{H}_{2} \mathrm{C}=\mathrm{SiH}-\mathrm{CH}_{3}$ and ions.}

This compound is listed by Allendorf et al.(1992)[30] with $\Delta_{\mathrm{f}} H^{\circ}(298 \mathrm{~K})=86.6 \mathrm{~kJ}$ $\mathrm{mol}^{-1}$; and by Sukkaew et al. (2014) [16] with $\Delta_{\mathrm{f}} H^{\circ}(298 \mathrm{~K})=92.6$ and $90.2 \mathrm{~kJ} \mathrm{~mol}^{-1}$ for using G4 and G4MP2 methods. The present G3B3 calculation lists $\Delta_{\mathrm{f}} H^{\circ}(298 \mathrm{~K})=125.8 \pm 8$. $\mathrm{kJ} \mathrm{mol}^{-1}$.

Both ions were not reported in the literature and have no CAS numbers. The thermal electron G3B3 values are $\Delta_{\mathrm{f}} H^{\circ}(298 \mathrm{~K})=938.1 \pm 8 . \mathrm{kJ} \mathrm{mol}^{-1}$ for the cation $\mathrm{H}_{2} \mathrm{C}=\mathrm{SiH}-\mathrm{CH}_{3}{ }^{+}$and $\Delta_{\mathrm{f}} H^{\circ}(298 \mathrm{~K})=131.6 \pm 8 . \mathrm{kJ} \mathrm{mol}^{-1}$ for the anion $\mathrm{H}_{2} \mathrm{C}=\mathrm{SiH}-\mathrm{CH}_{3}{ }^{-}$.

\section{$\mathrm{C}_{2} \mathrm{H}_{8} \mathrm{Si}, \mathrm{C}_{2} \mathrm{H}_{8} \mathrm{Si}^{+}, \mathrm{C}_{2} \mathrm{H}_{8} \mathrm{Si}^{-}$Dimethylsilane $\mathrm{CH}_{3}-\mathrm{SiH}_{2}-\mathrm{CH}_{3}$ and ions.}

Heat of formation of dimethylsilane is reported by Becerra and Walsh (1998) [6] as $\Delta_{\mathrm{f}} H^{\circ}(298 \mathrm{~K})=-94.7 \pm 4 . \mathrm{kJ} \mathrm{mol}^{-1}$. The present G3B3 value is $\Delta_{\mathrm{f}} H^{\circ}(298 \mathrm{~K})=-88.2 \pm 8 . \mathrm{kJ} \mathrm{mol}^{-1}$.

The cation $\mathrm{CH}_{3}-\mathrm{SiH}_{2}-\mathrm{CH}_{3}{ }^{+}$and anion $\mathrm{CH}_{3}-\mathrm{SiH}_{2}-\mathrm{CH}_{3}{ }^{-}$were not reported and their thermal electron G3B3 values are $\Delta_{\mathrm{f}} H^{\circ}(298 \mathrm{~K})=893.3 \pm 8 . \mathrm{kJ} \mathrm{mol}^{-1}$ and $\Delta_{\mathrm{f}} H^{\circ}(298 \mathrm{~K})=$ $68.7 \pm 8 . \mathrm{kJ} \mathrm{mol}^{-1}$ respectively. The anion has no CAS No. 


\section{$\mathrm{C}_{2} \mathrm{H}_{8} \mathrm{Si}, \mathrm{C}_{2} \mathrm{H}_{8} \mathrm{Si}^{+}$Ethylsilane $\mathrm{C}_{2} \mathrm{H}_{5} \mathrm{SiH}_{3}$ and cation.}

Thermochemical data of ethylsilane was reported in the literature by Gordon, Boatz and Walsh (1989) [38] as $\Delta_{\mathrm{f}} H^{\circ}(298 \mathrm{~K})=-37.7 \mathrm{~kJ} \mathrm{~mol}^{-1}$; by Tel'noi and Rabinovitch (1980) [39] $\Delta_{\mathrm{f}} H^{\circ}(298 \mathrm{~K})=-34.3 \mathrm{~kJ} \mathrm{~mol}^{-1}$ and the present G3B3 calculation reads $\Delta_{\mathrm{f}} H^{\circ}(298 \mathrm{~K})=-$ $36.1 \pm 8 . \mathrm{kJ} \mathrm{mol}^{-1}$.

The cation $\mathrm{C}_{2} \mathrm{H}_{5} \mathrm{SiH}_{3}{ }^{+}$thermal electron $\mathrm{G} 3 \mathrm{~B} 3$ value reads $\Delta_{\mathrm{f}} H^{\circ}(298 \mathrm{~K})=930 . \pm 8 . \mathrm{kJ}$ $\mathrm{mol}^{-1}$.

\section{$\mathrm{C}_{3} \mathrm{H}_{9} \mathrm{Si}$ Trimethylsilyl radical $\left(\mathrm{CH}_{3}\right)_{3} \mathrm{Si}^{*}$.}

The radical trimethylsilyl is reported in the Chemkin database (1982) [13] with $\Delta_{\mathrm{f}} H^{\circ}(298 \mathrm{~K})=13 . \mathrm{kJ} \mathrm{mol}^{-1}$. Kalinovski, Gutman et al. (1994) [40] report $\Delta_{\mathrm{f}} H^{\circ}(298 \mathrm{~K})=$ $68.6 \pm 25 . \mathrm{kJ} \mathrm{mol}^{-1}$. Becerra and Walsh (1998) [6] report $\Delta_{\mathrm{f}} H^{\circ}(298 \mathrm{~K})=15 . \pm 7 . \mathrm{kJ} \mathrm{mol}^{-1}$. The present G3B3 value is $\Delta_{\mathrm{f}} H^{\circ}(298 \mathrm{~K})=24.2 . \pm 8 . \mathrm{kJ} \mathrm{mol}^{-1}$.

\section{$\mathrm{C}_{3} \mathrm{H}_{10} \mathrm{Si}$ Trimethylsilane $\left(\mathrm{CH}_{3}\right)_{3} \mathrm{SiH}$.}

Trimethylsilane was published in the Chemkin thermochemical database (1982) [13] with $\Delta_{\mathrm{f}} H^{\circ}(298 \mathrm{~K})=-164.8 \mathrm{~kJ} \mathrm{~mol}^{-1}$. Doncaster and Walsh (1986) [41] report an experimental value of $\Delta_{\mathrm{f}} H^{\circ}(298 \mathrm{~K})=-163.4 \pm 4 . \mathrm{kJ} \mathrm{mol}^{-1}$. Allendorf and Melius (1992) [30] report $\Delta_{\mathrm{f}} H^{\circ}(298 \mathrm{~K})=-163.6 \mathrm{~kJ} \mathrm{~mol}^{-1}$. The present G3B3 value lists $\Delta_{\mathrm{f}} H^{\circ}(298 \mathrm{~K})=-153.2 \pm 8$. $\mathrm{kJ} \mathrm{mol}^{-1}$.

\section{$\mathrm{C}_{4} \mathrm{H}_{12} \mathrm{Si}, \mathrm{C}_{4} \mathrm{H}_{12} \mathrm{Si}^{+}$Tetramethylsilane $\left(\mathrm{CH}_{3}\right)_{4} \mathrm{Si}$ and cation.}

The heat of formation of tetramethylsilane is reported by JANAF (1960) [3] as $\Delta_{\mathrm{f}} H^{\circ}(298 \mathrm{~K})=-286.6 \mathrm{~kJ} \mathrm{~mol}^{-1}$. Becerra and Walsh $(1998)[6]$ report $\Delta_{\mathrm{f}} H^{\circ}(298 \mathrm{~K})=-229 . \pm 3$. to $-233.2 \pm 3.2 \mathrm{~kJ} \mathrm{~mol}^{-1}$. The present G3B3 calculation lists $\Delta_{\mathrm{f}} H^{\circ}(298 \mathrm{~K})=-219.3 \pm 8 . \mathrm{kJ}$ $\mathrm{mol}^{-1}$.

The tetramethylsilane cation $\mathrm{C}_{4} \mathrm{H}_{12} \mathrm{Si}^{+}$is calculated for the first time and thermal electron G3B3 value is $\Delta_{\mathrm{f}} H^{\circ}(298 \mathrm{~K})=706.5 \pm 8 . \mathrm{kJ} \mathrm{mol}^{-1}$.

\section{$\mathrm{C}_{4} \mathrm{H}_{12} \mathrm{Si}, \mathrm{C}_{4} \mathrm{H}_{12} \mathrm{Si}^{+}$Diethylsilane $\left(\mathrm{C}_{2} \mathrm{H}_{5}\right)_{2} \mathrm{SiH}_{2}$ and cation.}

Thermochemical data of diethylsilane was reported by Pedley and Rylance (1977) [42] as $\Delta_{\mathrm{f}} H^{\circ}(298 \mathrm{~K})=-182 . \pm 6 . \mathrm{kJ} \mathrm{mol}^{-1}$; by Walsh and coworkers (1989) [38] $\Delta_{\mathrm{f}} H^{\circ}(298 \mathrm{~K})$ $=-117.2 \mathrm{~kJ} \mathrm{~mol}^{-1}$. The G3B3 calculation result in $\Delta_{\mathrm{f}} H^{\circ}(298 \mathrm{~K})=-106.0 \pm 8 . \mathrm{kJ} \mathrm{mol}^{-1}$. 
The thermal electron G3B3 value of the cation $\left(\mathrm{C}_{2} \mathrm{H}_{5}\right)_{2} \mathrm{SiH}_{2}{ }^{+}$is $\Delta_{\mathrm{f}} \mathrm{H}^{\circ}(298 \mathrm{~K})=$ $821.3 \pm 8 . \mathrm{kJ} \mathrm{mol}^{-1}$.

\section{$\mathrm{C}_{6} \mathrm{H}_{8} \mathrm{Si}, \mathrm{C}_{6} \mathrm{H}_{8} \mathrm{Si}^{-}$, Phenylsilane $\mathrm{C}_{6} \mathrm{H}_{5}-\mathrm{SiH}_{3}$ and anion}

To the best of our knowledge the enthalpy of formation of phenylsilane, diphenylsilane, triphenylsilane and tetraphenylsilane were never published. Therefore this is the first calculation of phenylsilane using the G3B3 method, which gives $\Delta_{\mathrm{f}} H^{\circ}(298 \mathrm{~K})=$ $123.06 \pm 8 . \mathrm{kJ} \mathrm{mol}^{-1}$. The multi phenylsilanes exceed our computational capacities.

The thermal electron G3B3 value of the phenylsilane anion $\mathrm{C}_{6} \mathrm{H}_{5}-\mathrm{SiH}_{3}{ }^{-}$lists $\Delta_{\mathrm{f}} H^{\circ}(298 \mathrm{~K})=164.7 \pm 8 . \mathrm{kJ} \mathrm{mol}^{-1}$.

As can be seen from the above report in some cases the results differ between different authors very much and in other cases they agree around some value. Mostly the differences are coming from different advanced experimental as well as computational techniques and resources, which were available at the time of reporting. There are explanations in the different cited articles about this behavior. The most interesting article in this category is that of Prascher et al. (2009) [49] where calculations were performed

with the CCSD(T) method using 29 different basis sets and differences of $8 \mathrm{kcal} \mathrm{mol}^{-1}$ for $\mathrm{SiH} ; 5 \mathrm{kcal} \mathrm{mol}^{-1}$ for SiF; $23 \mathrm{kcal} \mathrm{mol}^{-1}$ for $\mathrm{SiH}_{4} ; 48 \mathrm{kcal} \mathrm{mol}^{-1}$ for $\mathrm{SiF}_{2} ; 90 \mathrm{kcal} \mathrm{mol}^{-1}$ for $\mathrm{SiF}_{4}$, etc. were obtained. Many of the data obtained by GA (group additivity) calculations differ from the rest as already pointed out by Becerra and Walsh [6]. Most of them were not quoted for this reason in the article. The most striking case is the RMG database [17] where the silicon data are relatively new (2016), and where the difference from other data usually is the highest, due to the erroneously use of carbon instead of silicon group additivity data.

\section{ERRORS}

The errors reported in this article are the original values reported in the literature cited. Where no error was given the values were published as it was found. In our G3B3 calculation we have assigned the mean absolute deviation assigned by Baboul et al. [21] "slightly less than $1 \mathrm{kcal} / \mathrm{mol}$ or better". The result uncertainty that represents $\pm 2 \sigma$ of the statistical normal distribution curve which is $\sim 96 \%$ confidence limit of the data should be therefore $\pm 8 . \mathrm{kJ} \mathrm{mol}^{-1}$ [66]. However as explained in the introduction, because of some uncertainty in the value of the enthalpy of formation of the pure elementary silicon in 
gaseous state, the error of all compounds containing more than three silicon atoms was increased.

\section{CONCLUSION}

The thermochemistry of 112 inorganic silicon containing species and 35 organic silicon containing species were calculated for ideal gas conditions in the temperature range of $200 \mathrm{~K}$ to $6000 \mathrm{~K}$ and 1 bar by the G3B3 composite method. The enthalpy of formation at 298.15 K was compared with literature values, if available. The thermochemical data calculated are presented as NASA 7 term format polynomials in the supplement of this article.

\section{SUPPLEMENTARY MATERIAL}

The supplement to this article contains the vibrations and moments of inertia used to calculate the thermochemical data reported. It also contains the NASA 7 term polynomials for calculation of the thermochemical data of all the species reported. The supplement can be found in the online version of this article.

\section{ACKNOWLEDGEMENT}

Funding by the energy, combustion, and gasturbine technology program (EVG) of Deutsches Zentrum für Luft- und Raumfahrt e. V. (DLR), the German Aerospace Center, is gratefully acknowledged.

\section{BIBLIOGRAPHY}

1. Walsh, R. In The Chemistry of Organic Silicon Compounds; Patai, S.; Rappoport, Z., Eds.; Wiley, 1989; Thermochemistry, Chapter 5, pages 371-391.

2. Haar L.; Friedman, A.S.; Beckett C.W.; Ideal Gas Thermodynamic Functions and Isotope Exchange Functions for the Diatomic Hydrides, Deuterides, and Tritides; NBS Monograph 20, United States Department of Commerce, National Bureau of Standards, Washington, DC, 1961.

3. JANAF thermochemical tables, series of loose leaves, distributed within US government agencies, 1960 and following years.

3a. Stull, D.R.; Prophet, H.; JANAF thermochemical tables, second edition, NBS National Standard Reference Data Series (NSRDS) - NBS 37, 1971.

3b. Chase M.W. Jr.; Curnutt, J.L.; McDonald, R.A.; Syverud, A.N.; JANAF Thermochemical Tables, J Phys Chem Ref Data 1978, Supplement, Vol. 7, No. 3, 793-940. 
3c. Chase, M. W. Jr.; Curnutt, J. L.; Downey, J. R. Jr.; McDonald, R. A.; Syverud, A. N.; Valenzuela, E. A.; JANAF Thermochemical Tables, J Phys Chem Ref Data 1982 Supplement, Vol. 11, No. 3, 695-940.

3d. Chase, M. W. Jr.; Davies, C.A.; Downey, J. R. Jr.; Frurip, D. J.; McDonald, R. A.; Syverud, A. N. JANAF thermochemical tables; 3rd edition; J Phys Chem Ref Data 1985, 14, 1-1856, Suppl. No. 1.

4. Glushko, V. P.; Gurvich, L.V.; Bergman, G.A.; Veyts, I.V.; Medvedev , V.A.; Khachkuruzov, G.A.; Yungman, V.S. Thermodynamic Properties of Pure Substances 1970 (in Russian).

5. Gurvich, V. N.; Veyts, L. V.; Alcock, C. B. Thermodynamic Properties of Individual Substances; $4^{\text {th }}$ edition; Hemisphere; New York, 1992.

6. Becerra, R.; Walsh, R. In The Chemistry of Organic Silicon Compounds; Rappoport, Z.; Appeloig, Y., Ed.; Wiley, 1998, Vol 2, Chapter 4 (Thermochemistry), pages 153-180.

7. Ochterski, J. W.; Petersson G. A.; Wiberg K. B.; A Comparison of Model Chemistries, J Am Chem Soc 1995, 117, 11299-11308. DOI: 10.1021/ja00150a030

8. Boo, B. H; Armentrout P.B.; Reaction of Silicon Ion $\left({ }^{2} \mathrm{P}\right)$ with Silane $\left(\mathrm{SiH}_{4}, \mathrm{SiD}_{4}\right)$. Heats of Formation of $\mathrm{SiH}_{n}, \mathrm{SiH}_{n}{ }^{+}(\mathrm{n}=1,2,3)$ and $\mathrm{Si}_{2} \mathrm{H}_{n}{ }^{+}(\mathrm{n}=0,1,2,3)$. Remarkable Isotope Exchange Reaction Involving Four Hydrogen Shifts. J Am Chem Soc 1987, 109, 35493559. DOI: 10.1021/ja00246a010

9. Wong H.-W.; Nieto J. C. A.; Swihart M. T.; Broadbelt L. J.; Thermochemistry of Silicon-Hydrogen Compounds Generalized From Quantum Chemical Calculations; J Phys Chem A 2004, 108, 874-897. DOI: 10.1021/jp030727k

10. Ho, P.; Melius, C. F.; A theoretical Study of the thermochemistry of $\mathrm{SiF}_{n}$ and $\mathrm{SiH}_{n} \mathrm{~F}_{m}$ compounds and $\mathrm{Si}_{2} \mathrm{~F}_{6}$; J Phys Chem 1990, 94, 5120-5127.

11. Ho, P.; Coltrin, M. E.; Binkley, J. S.; Melius; C. F., Theoretical study of the heats of formation of $\mathrm{Si}_{2} \mathrm{H}_{n}(\mathrm{n}=0-6)$ compounds and trisilane, J Phys Chem 1986, 90, 3399-3406. DOI: $10.1021 / \mathrm{j} 100406 \mathrm{a} 019$

12. Allendorf, M. D.; Melius, C. F.; Ho, P.; Zachariah, M. R.; Theoretical study of the Thermochemistry of Molecules in the Si-O-H System; J Phys Chem 1995, 99, 1528515293. 
13. CHEMKIN, a program to calculate chemical kinetics problems, developed by SANDIA and marketed by "Reaction Design" San Diego, CA, USA. Includes a Thermochemical database and Fitdat, a program to calculate NASA type thermochemical polynomials.

14.

Lyman J.L.; Noda T., Thermochemical Properties of $\mathrm{Si}_{2} \mathrm{~F}_{6}$ and $\mathrm{SiF}_{4}$ in Gas and Condensed Phases, J Phys Chem Ref Data, 2001, 30, 165-186. Doi: 10.1063/1.1364519

15.

Lias, S. G.; Bartmess, J. E.; Liebman, J. F.; Holmes, J. L.; Levin, R.D.; Mallard, W.G., Gas-Phase Ion and Neutral Thermochemistry, J Phys Chem Ref Data 1988, Vol 17, Supplement 1, 1-861.

16. Sukkaew, P; Ojamäe L.; Danielsson Ö.; Kordina O.; Janzén, E.; Revisiting the Thermochemical Database of Si-C-H System Related to SiC CVD Modeling, Material Science Forum 2014, Volumes 778-780, 175-178. DOI 10.4028/www.scientific.net/MSF.778-780.175

17. Green, W.H. and West R.H.; RMG (Reaction Mechanism Generator) program. 2017 <rmg.mit.edu>. RMG Molecule search : http://rmg.mit.edu/molecule_search

18.

Slakman, B. L.; Simka, H.; Reddy, H.; West; R. H., Extending Reaction Mechanism Generator to Silicon Hydride Chemistry; Ind Eng Chem Res 2016, 55, 12507-12515.

DOI: $10.1021 /$ acs.iecr.6b02402

19. Goos E., Burcat A., Ruscic, B. Extended Third Millennium Ideal Gas and Condensed Phase Thermochemical Database for Combustion with Updates from Active Thermochemical Tables, 2017, <http://burcat.technion.ac.il>

Electronic update of Burcat A., Ruscic, B. Third Millennium Ideal Gas and Condensed Phase Thermochemical Database for Combustion with Updates from Active Thermochemical Tables, Report ANL-05/20 and TAE 960, Argonne National Laboratory, and Technion, Israel Institute of Technology, 2005.

20. McBride B. J.; Gordon, S., Computer Program for Calculating and Fitting Thermodynamic Functions, NASA RP-1271; 1992.

21. Baboul, A. G.; Curtiss, L.A.; Redfern, P.C.; Raghavachari, K.; Gaussian-3 theory using density functional geometries and zero point energies. J Chem Phys 1999, 110, 76507657. Doi 10.1063/1.478676 
22. Gaussian 03, Revision B.02, M. J. Frisch, G. W. Trucks, H. B. Schlegel, J.A. Pople et al. Gaussian, Inc, Pittsburg PA, 2003.

23. Chem3D is a "CambrigeSoft" program for molecular modelling and display with semi-empirical calculations built in with the Mopac 2000 application.

24. Huber, K. P.; Herzberg, G., Molecular Spectra and Molecular Structure, IV. Constants of Diatomic Molecules, Van Nostrand Reinhold, New York, (1977) as reprinted in $<$ Webbook.NIST.GOV>

25. NIST Computational Chemistry Comparison and Benchmark Database, NIST Standard Reference Database Number 101, Release 18, October 2016, Editor: Russell D. Johnson III, <http://cccbdb.nist.gov/>.

26. Irikura K. K.; Johnson III, R. D.; Kacker, R. N., Uncertainties in Scaling Factors for ab Initio Vibrational Frequencies, J Phys Chem A 2005, 109, 8430-8437. DOI: 10.1021/jp052793n

27. Kawamata, H.; Negishi, Y.; Kishi, R.; Iwata S.; Nakajima, A.; Kaya K., Photoelectron spectroscopy of silicon-fluorine binary cluster anions $\left(\mathrm{Si}_{n} \mathrm{~F}_{\mathrm{m}}{ }^{-}\right)$, J Chem Phys 1996, 105, 5369-5376. http://dx.doi.org/10.1063/1.472377

28. Weber, M. E.; Armentrout, P. B. Energetics and dynamics in the reaction of $\mathrm{Si}^{+}$with $\mathrm{SiF}_{4}$. Thermochemistry of $\mathrm{SiF}_{\mathrm{x}}$ and $\mathrm{SiF}_{\mathrm{x}}{ }^{+}(\mathrm{x}=1,2,3)$, J Chem Phys 1988, 88, 6898-6910. DOI 10.1063/1.454387

29. Walsh R., Thermochemistry of Silicon-containing Compounds. Part 1.-SiliconHalogen Compounds, an Evaluation, J Chem Soc Faraday Trans 1, 1983, 79, 22332248. DOI 10.1039/F19837902233

30. Allendorf M. D.; Melius, C.F., Theoretical Study of the Thermochemistry of Molecules in the Si-C-H System, J Phys Chem 1992, 96, 428-437. DOI 10.1021/j100180a080

31. Katzer, G.; Ernst, M. C.; Sax, A. F.; Kalcher, J.; Computational thermochemistry of medium-sized silicon hydrides, J Phys Chem A 1997, 101, 3942-3958. DOI 10.1021/jp9631947

32. Swihart M. T., Girshick S. L., Thermochemistry and Kinetics of Silicon Hydride Cluster Formation during Thermal Decomposition of Silane, J Phys Chem B 1999,103, 64-76.

33. Benson, S.W. Thermochemical Kinetics, Wiley, New York, 1976. 
34. HSC Thermochemical database (1999)

35. Ruscic B.; Berkowitz, J.; Photoionization mass spectrometric studies of the transient species $\mathrm{Si}_{2} \mathrm{H}_{\mathrm{n}}(\mathrm{n}=2-5)$, J Chem Phys 1991, 95, 2416-2432.

http://dx.doi.org/10.1063/1.460947

36. Berkowitz, J; Greene, J. P.; Cho, H.; Ruscic B. Photoionization mass spectrometric studies of $\mathrm{SiH}_{n}(\mathrm{n}=1-4)$, J Chem Phys 1987, 86, 1235-1248.

37. McBride B.J. The NASA Thermochemical database, last updated in 2003. https://www.grc.nasa.gov/www/CEAWeb/ceaThermoBuild.htm

38. Gordon, M. S.; Boatz, J. A.; Walsh, R., Heats of Formation of Alkylsilanes, J Phys Chem 1989, 93, 1584-1585.

39. Tel'noi, V. I.; Rabinovich I. B., Thermochemistry of Organic Derivatives of Nontransition Elements, Russ Chem Review 1980, 49, 603-622.

40. Kalinovski, I. J.; Gutman, D.; Krasnoperov, L. N.; Goumri, A.; Yuan, W.-J.; Marshall, P., Kinetics and Thermochemistry of the Reaction $\mathrm{Si}\left(\mathrm{CH}_{3}\right)_{3}+\mathrm{HBR} \rightleftharpoons \mathrm{Si}\left(\mathrm{CH}_{3}\right)_{3} \mathrm{H}+\mathrm{Br}$ : Determination of the $\left(\mathrm{CH}_{3}\right)_{3} \mathrm{Si}-\mathrm{H}$ Bond Energy, J Phys Chem 1994, 98, 9551-9557.

41. Doncaster, A. M.; Walsh, R., Thermochemistry of Silicon-containing Compounds. Part 2. -The Enthalpies of Formation of the Methylsilanes, an Experimental Study and Review, J Chem Soc Faraday Trans 2, 1986, 82, 707-717. DOi 10.1039/F29868200707

42. Pedley J. B.; Rylance, J., Sussex-N.P.L. Computer Analyzed Thermochemical Data: Organic and Organometallic Compounds; University of Sussex, 1977.

43. Feller, D.; Dixon, D. A., Theoretical Study of the Heats of Formation of Small SiliconContaining Compounds; J Phys Chem A 1999, 103, 6413-6419. DOI 10.1021/jp990596g

44. Grev, R. S.; Schaefer III, H. F., Thermochemistry of $\mathrm{CH}_{n}, \mathrm{SiH}_{\mathrm{n}}(\mathrm{n}=0-4)$, and the cations $\mathrm{SiH}^{+}, \mathrm{SiH}_{2}{ }^{+}$and $\mathrm{SiH}_{3}{ }^{+}$: A converged quantum mechanical approach, J Chem Phys 1992, 97, 8389-8406.

45. Jursic B.S., A B3LYP hybrid density functional theory study of structural properties, energies, and heats of formation for silicon-hydrogen compounds, J Mol Struct THEOCHEM 2000, 497, 65-73. DOI: 10.1016/S0166-1280(99)00197-9 
46. Jalbout, A.F.; Swihart, M. T.; Jursic, B.S.; Corrigendum to "Potential energy surface for $\mathrm{H}_{2} \mathrm{Si}_{2}$ isomers explored with complete basis set ab initio method" [J. Mol. Struct. (Theochem) 1999, 459, 221-228.], J Mol Struct: THEOCHEM, 2001, 571 (1-3), 231-232. https://doi.org/10.1016/S0166-1280(01)00584-X

47. Michels, H. H.; Hobbs, R. H., Electronic structure and thermochemistry of silicon hydride and silicon fluoride anions, Chem Phys Letters 1993, 207, 389-396.

https://doi.org/10.1016/0009-2614(93)89019-E

48. Takhistov, V. V.; Golovin, A. V., Thermochemistry of organic, heteroorganic and inorganic species. XV. The enthalpies of formation for halogenides of main group elements, J Molec Struct 2006, 784, 47-68.

https://doi.org/10.1016/j.molstruc.2005.06.028

49. Prascher, B. P.; Lucente-Schultz, R. M.; Wilson, A. K.; A CCSD(T) and ccCA study of mixed silicon hydrides and halides: Structures and thermochemistry, Chem Phys 2009, 359, 1-13. https://doi.org/10.1016/j.chemphys.2009.02.009

50. Cox, J. D.; Wagman, D. D.; Medvedev, V. A., CODATA Key Values for Thermodynamics, Hemisphere Publishing Corp., New York, 1984.

51. Wang, L.-S.; Wu, H.; Desai, S. R.; Fan, J.; Colson, S. D.; A Photoelectron Spectroscopic Study of Small Silicon Oxide Clusters: $\mathrm{SiO}_{2}, \mathrm{Si}_{2} \mathrm{O}_{3}$, and $\mathrm{Si}_{2} \mathrm{O}_{4}$, J Phys Chem 1996, 100 , 8697-8700. DOI: 10.1021/jp9602538

52. Karton A.; Martin J. M. L.; Heats of Formation of Beryllium, Boron, Aluminum, and Silicon Re-examined by Means of W4 Theory; J Phys Chem A 2007, 111, 5936-5944. DOI: 10.1021/jp071690x

53. Hidding, B; Pfitzner, M., Rocket Propellant Characteristics of Silanes $/ \mathrm{O}_{2}$, J Propulsion Power 2006, 22, 786-789. DOI 10.2514/1.17996

54. Danovich, D.; Ogliaro, F.; Karni, M.; Apeloig, Y.; Cooper, D. L.; Shaik, S.; Silynes

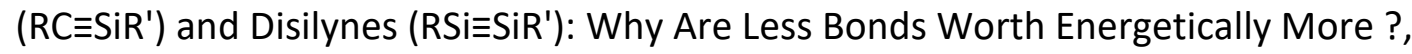
Angew Chem Int Ed 2001, 40(21), 4023-4026. DOI 10.1002/1521-

3773(20011105)40:21<4023::AID-ANIE4023>3.0.CO;2-Z

55. Dolgonos, G.; Relative stability and thermodynamic properties of $\mathrm{Si}_{2} \mathrm{H}_{4}$ isomers; Chem Phys Letters 2008, 466(1-3), 11-15. DOI: 10.1016/j.cplett.2008.10.017

56. Becerra, R.; Walsh, R.; Mechanism of Formation of Tri- and Tetrasilane in the Reaction of Atomic Hydrogen with Monosilane and the Thermochemistry of the 
$\mathrm{Si}_{2} \mathrm{H}_{4}$ Isomers, J Phys Chem 1987, 91(22), 5765-5770.

https://pubs.acs.org/doi/abs/10.1021/j100306a049

57. Curtis, L. A.; Raghavachari, K.; Deutsch, P. W.; Pople, J. A.; Theoretical study of $\mathrm{Si}_{2} \mathrm{H}_{\mathrm{n}}$ $(n=0-6)$ and $\mathrm{Si}_{2} \mathrm{H}_{n}^{+}(\mathrm{n}=0--7)$ : Appearance potentials, ionization potentials, and enthalpies of formation J Chem Phys 1991, 95,2433-2444.

58. Sax, A. F.; Kalcher, J.; Theoretical enthalpies of formation for small silicon hydrides; J Phys Chem 1991, 95, 1768-1783. https://pubs.acs.org/doi/abs/10.1021/j100157a052

59. Boatz, J. A.; Gordon, M. S.; Predicted enthalpies of formation for silaethylene, disilene, and their silylene isomers; J Phys Chem 1990, 94, 7331-7333.

https://pubs.acs.org/doi/abs/10.1021/j100382a001

60. Raghunath, P.; Lee, Y.-M.; Wu, S.-Y.; Wu, J.-S.; Lin, M.-C.; Ab Initio Chemical Kinetics for reactions of $\mathrm{H}$ atoms with $\mathrm{SiH}_{\mathrm{x}}(\mathrm{x}=1-3)$ Radicals and Related Unimolecular Decomposition Processes, Int J Quantum Chem 2013, 113, 1735-1746. DOI: 10.1002/qua.24396

61. Nguyen, T.-N.; Lee, Y.-M.; Wu, J.-S.; Lin, M.-C.; Capturing $\mathrm{H}$ and $\mathrm{H}_{2}$ by $\mathrm{SiH}_{\mathrm{x}}{ }^{+}(\mathrm{x} \leq 4)$ ions: Comparison between Langevin and quantum statistical models, Jpn J Appl Phys 2017, 56, 026101. http://stacks.iop.org/1347-4065/56/i=2/a=026101

62. Nguyen, T.-N.; Lin, M.C.; Ab Initio Chemical Kinetics for $\mathrm{SiH}_{\mathrm{x}}$ Reactions with $\mathrm{Si}_{2} \mathrm{H}_{\mathrm{y}}$ $(x=1,2,3,4 ; y=6,5,4,3 ; x+y=7)$ under a-Si:H CVD Condition; Int J Chem Kinet 2017, 49, 197-208. DOI: 10.1002/kin.21067

63. Nguyen, T. N.; Lee, Y. M.; Wu, J. S.; Lin, M. C; Ab Initio Chemical Kinetics for the Thermal Decomposition of $\mathrm{SiH}_{4}{ }^{+}$Ion and Related Reverse Ion-Molecule Reactions of Interest to PECVD of a-Si:H Films, Plasma Chem Plasma Process 2017, 37, 1249-1264. https://doi.org/10.1007/s11090-017-9825-7

64. Raghunath, P.; Lin, M.C. ; Ab Initio Chemical Kinetics for $\mathrm{SiH}_{2}+\mathrm{Si}_{2} \mathrm{H}_{6}$ and $\mathrm{SiH}_{3}+$ $\mathrm{Si}_{2} \mathrm{H}_{5}$ Reactions and the Related Unimolecular Decomposition of $\mathrm{Si}_{3} \mathrm{H}_{8}$ under a-Si/H CVD Conditions, J Phys Chem A 2013, 117, 10811-10823. DOI: 10.1021/jp407553a

65. Ruscic, B.; Bross, D.H. Active Thermochemical Tables (ATcT) version 1.122 of the Thermochemical Network (2016); https://atct.anl.gov

66. Ruscic B. Uncertainty Quantification in Thermochemistry, Benchmarking Electronic Structure Computations, and Active Thermochemical Tables Int. J. Quantum Chem. 2014, 114, 1097-1101. DOI: 10.1002/qua.24605 
Table 1 Thermochemical properties of Inorganic Si containing compounds:

Molecular Weights, $\Delta_{\mathrm{f}} H_{298}, \Delta_{\mathrm{f}} H_{0}, C_{p 298}, \mathrm{~S}_{298}, H_{298}-H_{0}$. The standard state corresponds to a pressure of 1 bar and $298.15 \mathrm{~K}$.

\begin{tabular}{|c|c|c|c|c|c|c|c|}
\hline Compounds & $\begin{array}{r}\text { Mol. Wgt. } \\
\text { g/mol }\end{array}$ & $\begin{array}{r}\Delta_{\mathrm{f}} H_{298} \\
\mathrm{~kJ} / \mathrm{mol}\end{array}$ & $\begin{array}{r}\Delta_{\mathrm{f}} H_{0} \\
\mathrm{~kJ} / \mathrm{mol}\end{array}$ & $\begin{array}{l} \pm \mathrm{kJ} / \\
\mathrm{mol}\end{array}$ & $\begin{array}{l}C_{p 298} \\
\mathrm{~J} /(\mathrm{mol} \\
\mathrm{K})\end{array}$ & $\begin{array}{l}\mathrm{S}_{298} \\
\mathrm{~J} /(\mathrm{mol} \mathrm{K})\end{array}$ & $\begin{array}{l}H_{298-} H_{0} \\
\mathrm{~kJ} / \mathrm{mol}\end{array}$ \\
\hline SiF Monofluorosilicon radical & 47.08390 & -62.555 & -63.776 & \pm 8 . & 31.551 & 220.615 & 8.851 \\
\hline $\mathrm{SiF}^{+}$Monofluorosilicon cation & 47.08335 & 657.491 & 650.143 & \pm 20 . & 30.593 & 214.001 & 8.765 \\
\hline SiF $^{-}$Monofluorosilicon anion & 47.08445 & -87.869 & -83.036 & \pm 20 . & 32.550 & 216.367 & 8.968 \\
\hline $\mathrm{SiF}_{2}$ Difluorosilylene & 66.08231 & -630.8 & -626.2 & \pm 8 & 44.396 & 262.954 & 11.231 \\
\hline $\mathrm{SiF}_{2}^{+}$Difluorosilylene cation & 66.08176 & 429.400 & 423.96 & \pm 8 . & 43.488 & 261.852 & 11.247 \\
\hline $\mathrm{SiF}_{2}^{-}$Difluorosilylenene anion & 66.08285 & -661.0 & -654.7 & \pm 8 . & 47.004 & 266.168 & 11.614 \\
\hline $\mathrm{SiOF}_{2} \mathrm{O}=\mathrm{SiF}_{2}$ DiFluorooxysilane & 82.08171 & -899.008 & -895.73 & \pm 8 . & 57.762 & 277.687 & 13.109 \\
\hline $\mathrm{SiOF}_{2}^{+} \mathrm{O}=\mathrm{SiF}_{2}$ cation & 82.08116 & 247.409 & 243.780 & \pm 8 . & 59.201 & 281.730 & 13.649 \\
\hline $\mathrm{SiOF}_{2}^{-} \mathrm{O}=\mathrm{SiF}_{2}$ anion & 82.08225 & -1056.07 & -1047.1 & \pm 8 & 60.504 & 279.970 & 13.461 \\
\hline $\mathrm{SiF}_{3}$ Trifluorosilyl radical & 85.08071 & -993.365 & -990.4 & \pm 8 & 59.613 & 282.433 & 13.398 \\
\hline $\mathrm{SiHF}_{3}$ Trifluorosilane & 86.08865 & -1207.67 & -1200.5 & \pm 5.4 & 63.486 & 277.351 & 13.545 \\
\hline $\mathrm{SiHF}_{3}+$ Trifluorosilane cation & 86.08810 & 73.200 & 71.818 & \pm 8 & 74.988 & 291.332 & 15.874 \\
\hline $\mathrm{SiF}_{4}$ Tetrafluorosilane & 104.07911 & -1614.98 & -1609.4 & \pm 4.2 & 73.534 & 282.615 & 15.325 \\
\hline $\mathrm{SiF}_{4}+$ Tetrafluorosilane cation & 104.07856 & -81.09 & -83.341 & \pm 8.0 & 79.002 & 297.107 & 16.636 \\
\hline $\mathrm{SiF}_{4^{-}}$Tetrafluorosilane anion & 104.07966 & -1544.08 & -1534.93 & \pm 8 & 82.680 & 317.359 & 18.190 \\
\hline $\mathrm{SiH}$ & 29.09344 & 376.660 & 375.355 & \pm 8 & 29.209 & 192.745 & 8.656 \\
\hline $\mathrm{SiH}^{+}$ & 29.09289 & 1144.3 & 1136.89 & \pm 8 . & 29.555 & 192.472 & 8.686 \\
\hline $\mathrm{SiH}^{-}$ & 29.09399 & 298.812 & 303.800 & \pm 8 . & 29.259 & 187.615 & 8.660 \\
\hline SiD & 30.09960 & 368.749 & 367.565 & \pm 8 . & 29.555 & 198.661 & 8.686 \\
\hline $\mathrm{SiD}^{+}$ & 30.09905 & 1145.161 & 1125.31 & \pm 8 . & 29.516 & 193.017 & 8.684 \\
\hline SiT & 31.10155 & 369.096 & 367.882 & & 29.982 & 201.971 & 8.716 \\
\hline $\mathrm{SiD}_{2} \quad \mathrm{D}-\mathrm{Si}-\mathrm{D}$ & 32.11370 & 262.855 & 264.418 & \pm 8 . & 37.031 & 217.458 & 10.193 \\
\hline $\mathrm{SiD}_{2}^{+}$cation & 32.11315 & 1155.624 & 1150.938 & \pm 8. & 37.518 & 222.013 & 10.276 \\
\hline $\mathrm{SiD}_{2}^{-}$ & 32.11425 & 147.281 & 161.210 & \pm 8 . & 37.761 & 224.001 & 10.252 \\
\hline SiD3 & 34.12781 & 191.761 & 196.765 & \pm 8 . & 45.928 & 229.809 & 11.067 \\
\hline SiD3+ cation & 34.12726 & 996.129 & 988.839 & \pm 8. & 45.179 & 223.200 & 10.967 \\
\hline SiD3- anion & 34.12835 & 37.431 & 55.003 & \pm 8. & 45.331 & 224.113 & 10.894 \\
\hline $\mathrm{SiHT}_{3}$ Tritritiumsilane & 38.14159 & 27.610 & 36.134 & \pm 8 . & 53.868 & 234.262 & 11.781 \\
\hline
\end{tabular}




\begin{tabular}{|c|c|c|c|c|c|c|c|}
\hline Compounds & $\begin{array}{r}\text { Mol. Wgt. } \\
\text { g/mol }\end{array}$ & $\begin{array}{r}\Delta_{\mathrm{f}} H_{298} \\
\mathrm{~kJ} / \mathrm{mol}\end{array}$ & $\begin{array}{r}\Delta_{\mathrm{f}} H_{0} \\
\mathrm{~kJ} / \mathrm{mol}\end{array}$ & $\begin{array}{l} \pm \mathrm{kJ} / \\
\mathrm{mol}\end{array}$ & \begin{tabular}{|l|}
$C_{p 298}$ \\
$\mathrm{~J} /(\mathrm{mol}$ \\
$\mathrm{K})$
\end{tabular} & $\begin{array}{l}\mathrm{S}_{298} \\
\mathrm{~J} /(\mathrm{mol} \mathrm{K})\end{array}$ & $\begin{array}{l}\mathrm{H}_{298}-\mathrm{H}_{0} \\
\mathrm{~kJ} / \mathrm{mol}\end{array}$ \\
\hline $\begin{array}{l}{ }^{2} \mathrm{SiH}_{2} \text { Silicon dihydride singlete } \\
\text { radical }\end{array}$ & 30.10138 & 263.843 & 265.527 & \pm 8 & 34.742 & 207.584 & 10.001 \\
\hline $\begin{array}{l}{ }^{3} \mathrm{SiH}_{2} \text { Silicon dihydride triplete } \\
\text { radical }\end{array}$ & 30.10138 & 354.623 & 356.244 & \pm 8 & 35.460 & 215.360 & 10.065 \\
\hline $\mathrm{SiH}_{2}^{+}$Silicon dihydride cation & 30.10083 & 1156.920 & 1152.34 & \pm 8 . & 35.343 & 211.902 & 10.054 \\
\hline $\mathrm{SiH}_{2}^{-}$Silicon dihydride anion & 30.10193 & 153.720 & 161.565 & \pm 8 . & 35.067 & 213.949 & 10.023 \\
\hline $\mathrm{SiH}_{2} \mathrm{~T}_{2}$ Ditritiumsilane & 36.13348 & 30.086 & 39.077 & \pm 8 . & 49.675 & 226.033 & 11.263 \\
\hline $\mathrm{SiH}_{3}$ Silyl & 31.10932 & 195.569 & 201.090 & \pm 8 & 40.077 & 217.058 & 10.398 \\
\hline $\mathrm{SiH}_{3}^{+}$Silyl cation & 31.10877 & 988.889 & 988.206 & \pm 8 . & 39.544 & 210.564 & 10.342 \\
\hline $\mathrm{SiH}_{3}^{-}$Silyl anion & 31.10987 & 52.253 & 64.053 & \pm 8 & 38.758 & 211.838 & 10.260 \\
\hline $\mathrm{SiH}_{3} \mathrm{~T}$ Monotritiumsilane & 34.89487 & 32.451 & 41.815 & \pm 8 & 45.939 & 222.416 & 10.840 \\
\hline $\mathrm{SiH}_{4}$ Silane & 32.11726 & 34.7 & 44.319 & \pm 8.2 & 42.787 & 204.208 & 10.535 \\
\hline $\mathrm{SiH}_{4}^{+}$Silane cation & 32.11671 & 1144.596 & 1147.03 & \pm 8 & 51.119 & 215.286 & 11.525 \\
\hline $\mathrm{SiD}_{4}$ Tetradeuteriunsilane & 36.14191 & 22.792 & 31.610 & \pm 8 . & 52.240 & 219.352 & 11.537 \\
\hline $\mathrm{SiT}_{4}$ Tetratritiumsilane & 40.14970 & 17.344 & 25.330 & \pm 8 . & 58.469 & 226.904 & 12.370 \\
\hline $\mathrm{SiO}$ & 44.08490 & -102.223 & -103.381 & \pm 8 . & 29.899 & 211.591 & 8.715 \\
\hline $\mathrm{SiO}^{+}$cation & 44.08435 & 1020.495 & 1013.110 & \pm 8 . & 30.185 & 217.702 & 8.734 \\
\hline $\mathrm{SiO}^{-}$anion & 44.08545 & -117.002 & -112.018 & \pm 8 . & 30.459 & 218.277 & 8.754 \\
\hline $\mathrm{SiO}_{2}$ gas & 60.08430 & -322.070 & -321.432 & \pm 10 . & 45.674 & 233.390 & 11.260 \\
\hline $\mathrm{SiO}_{2}^{-}$anion & 60.08485 & -488.386 & -481.398 & \pm 8 & 42.656 & 256.257 & 11.039 \\
\hline $\mathrm{Si}_{2} \mathrm{~F}_{6}$ Hexafluorodisilane & 170.16142 & -2346.72 & -2340.59 & \pm 8 . & 128.567 & 404.351 & 26.782 \\
\hline $\begin{array}{l}\mathrm{Si}_{2} \mathrm{~F}_{6}^{+} \text {Hexafluorodisilane } \\
\text { cation }\end{array}$ & 170.16087 & -1205.09 & -1207.48 & \pm 8 & 130.849 & 433.135 & 28.747 \\
\hline $\mathrm{Si}_{2} \mathrm{~F}_{6}{ }^{-}$Hexafluorodisilane anion & 170.16197 & -2401.73 & -2391.39 & \pm 8 . & 136.436 & 411.445 & 28.461 \\
\hline $\begin{array}{ll}\mathrm{Si}_{2} \mathrm{OF}_{6} & \mathrm{~F}_{3} \mathrm{Si}-\mathrm{O}-\mathrm{SiF}_{3}\end{array}$ & 186.16082 & -2865.85 & -2857.61 & \pm 8 . & 138.522 & 446.199 & 29.015 \\
\hline
\end{tabular}




\begin{tabular}{|c|c|c|c|c|c|c|c|}
\hline Compounds & $\begin{array}{r}\text { Mol. Wgt. } \\
\text { g/mol }\end{array}$ & $\begin{array}{r}\Delta_{\mathrm{f}} H_{298} \\
\mathrm{~kJ} / \mathrm{mol}\end{array}$ & $\begin{array}{r}\Delta_{\mathrm{f}} H_{0} \\
\mathrm{~kJ} / \mathrm{mol}\end{array}$ & $\begin{array}{l} \pm \mathbf{k J} / \\
\mathrm{mol}\end{array}$ & $\begin{array}{l}C_{p 298} \\
\mathrm{~J} /(\mathrm{mol} \\
\mathrm{K})\end{array}$ & $\begin{array}{l}\mathrm{S}_{298} \\
\mathrm{~J} /(\mathrm{mol} \mathrm{K})\end{array}$ & $\begin{array}{l}\mathrm{H}_{298}-\mathrm{H}_{0} \\
\mathrm{~kJ} / \mathrm{mol}\end{array}$ \\
\hline $\begin{array}{l}\mathrm{Si}_{2} \mathrm{H} \mathrm{HSi}=\mathrm{Si} \text { Disilene } \\
\text { monohydrid }\end{array}$ & 57.17894 & 492.176 & 492.246 & \pm 8 . & 40.409 & 254.305 & 10.599 \\
\hline $\begin{array}{l}\mathrm{Si}_{2} \mathrm{D} \text { DSi }=\mathrm{Si} \text { Disilene } \\
\text { monodeuterid }\end{array}$ & 58.18510 & 493.18 & 491.35 & \pm 8 . & 46.438 & 284.446 & 12.607 \\
\hline $\mathrm{Si}_{2} \mathrm{H}_{2} \quad \mathrm{HSi}=\mathrm{SiH}$ Disilyne & 58.18688 & 452.119 & 453.439 & \pm 8 & 57.192 & 262.489 & 13.583 \\
\hline $\begin{array}{l}\mathrm{Si}_{2} \mathrm{H}_{2}+\mathrm{HSi}=\mathrm{SiH}+\text { Disilyne } \\
\text { cation }\end{array}$ & 58.18633 & 1267.00 & 1261.208 & \pm 8 . & 59.584 & 276.578 & 14.357 \\
\hline $\mathrm{Si}_{2} \mathrm{D}_{2} \quad \mathrm{DSi}=\mathrm{SiD}$ Disilyne-d2 & 60.19920 & 451.340 & 451.964 & \pm 8 . & 59.768 & 272.843 & 14.380 \\
\hline $\mathrm{Si}_{2} \mathrm{H}_{4} \mathrm{H}_{2} \mathrm{Si}=\mathrm{SiH}_{2}$ & 60.20276 & 273.136 & 282.273 & \pm 8 . & 70.016 & 262.567 & 14.234 \\
\hline $\mathrm{Si}_{2} \mathrm{H}_{4}{ }^{+} \mathrm{H}_{2} \mathrm{Si}=\mathrm{SiH}_{2}$ cation & 60.20221 & 1066.000 & 1068.288 & \pm 8 & 71.846 & 265.111 & 14.613 \\
\hline $\mathrm{Si}_{2} \mathrm{H}_{4} \quad \mathrm{H}_{3} \mathrm{Si}-\mathrm{SiH}$ & 60.20276 & 304.231 & 312.848 & \pm 8 . & 69.895 & 280.449 & 14.754 \\
\hline $\mathrm{Si}_{2} \mathrm{H}_{4}+\mathrm{H}_{3} \mathrm{Si}-\mathrm{SiH}+$ cation & 60.20276 & 1121.250 & 1122.709 & \pm 8 . & 72.353 & 286.811 & 14.975 \\
\hline $\mathrm{Si}_{2} \mathrm{H}_{4^{-}} \quad \mathrm{H}_{3} \mathrm{Si}-\mathrm{SiH}-$ anion & 60.20331 & 138.975 & 153.737 & \pm 8 . & 69.440 & 284.039 & 14.468 \\
\hline $\mathrm{Si}_{2} \mathrm{H}_{5} \quad \mathrm{H}_{3} \mathrm{Si} \mathrm{SiH}_{2}{ }^{*}$ & 61.21070 & 227.220 & 239.884 & \pm 8 . & 76.052 & 295.764 & 14.942 \\
\hline $\begin{array}{l}\mathrm{Si}_{2} \mathrm{H}_{5^{-}} \quad \mathrm{H}_{3} \mathrm{Si}_{-} \mathrm{SiH}_{2}{ }^{*} \text { - radical } \\
\text { anion }\end{array}$ & 61.21125 & 39.329 & 57.710 & \pm 8 . & 75.852 & 295.424 & 14.810 \\
\hline $\mathrm{Si}_{2} \mathrm{H}_{6}$ Disilane $\mathrm{H}_{3} \mathrm{Si}_{-} \mathrm{SiH}_{3}$ & 62.21864 & 80.3 & 96.502 & \pm 1.5 & 77.260 & 274.605 & 15.638 \\
\hline $\mathrm{Si}_{2} \mathrm{H}_{6}{ }^{+} \mathrm{H}_{3} \mathrm{Si}-\mathrm{SiH}_{3}$ cation & 62.21809 & 1016.014 & 1022.833 & \pm 8 . & 90.949 & 302.371 & 17.963 \\
\hline $\mathrm{Si}_{3} \mathrm{H}_{5} \mathrm{SiH}_{2}=\mathrm{SiH}-\mathrm{SiH}_{2}$ & 89.29620 & 433.257 & 444.025 & \pm 8 . & 103.073 & 336.958 & 20.055 \\
\hline $\mathrm{Si}_{3} \mathrm{H}_{5}{ }^{+} \mathrm{SiH}_{2}=\mathrm{SiH}-\mathrm{SiH}_{2}$ cation & 89.29565 & 1107.610 & 1111.848 & \pm 8 . & 100.783 & 340.465 & 19.973 \\
\hline $\mathrm{Si}_{3} \mathrm{H}_{5}^{-} \mathrm{SiH}_{2}=\mathrm{SiH}-\mathrm{SiH}_{2}$ anion & 89.29675 & 209.000 & 225.513 & \pm 8. & 101.867 & 331.845 & 20.079 \\
\hline $\mathrm{Si}_{3} \mathrm{H}_{5}$ Cyclotrisilanyl & 89.29620 & 387.024 & 399.641 & \pm 8 . & 99.539 & 314.302 & 18.206 \\
\hline $\mathrm{Si}_{3} \mathrm{H}_{5}{ }^{+}$Cyclotrisilanyl cation & 89.29565 & 1096.095 & 1101.488 & \pm 8 . & 98.930 & 318.325 & 18.785 \\
\hline $\mathrm{Si}_{3} \mathrm{H}_{5}^{-}$Cyclotrisilanyl anion & 89.29675 & 147.948 & 166.494 & \pm 8 . & 98.121 & 307.705 & 18.005 \\
\hline $\mathrm{Si}_{3} \mathrm{H}_{6}$ Cyclotrisilane & 90.30414 & 257.314 & 273.626 & \pm 8 . & 105.306 & 304.512 & 18.965 \\
\hline
\end{tabular}




\begin{tabular}{|c|c|c|c|c|c|c|c|}
\hline Compounds & $\begin{array}{r}\text { Mol. Wgt. } \\
\text { g/mol }\end{array}$ & $\begin{array}{r}\Delta_{\mathrm{f}} H_{298} \\
\mathrm{~kJ} / \mathrm{mol}\end{array}$ & $\begin{array}{r}\Delta_{\mathrm{f}} H_{0} \\
\mathrm{~kJ} / \mathrm{mol}\end{array}$ & $\begin{array}{l} \pm \mathrm{kJ} / \\
\mathrm{mol}\end{array}$ & $\begin{array}{l}C_{p 298} \\
\mathrm{~J} /(\mathrm{mol} \\
\mathrm{K})\end{array}$ & $\begin{array}{l}\mathrm{S}_{298} \\
\mathrm{~J} /(\mathrm{mol} \mathrm{K})\end{array}$ & $\begin{array}{l}\mathrm{H}_{298}-\mathrm{H}_{0} \\
\mathrm{~kJ} / \mathrm{mol}\end{array}$ \\
\hline $\mathrm{Si}_{3} \mathrm{H}_{6}^{+}$Cyclotrisilane cation & 90.30359 & 1063.513 & 1071.472 & \pm 8 . & 111.575 & 319.427 & 20.369 \\
\hline $\mathrm{Si}_{3} \mathrm{H}_{6}^{-}$Cyclotrisilane anion & 90.30469 & 289.248 & 310.386 & \pm 8 & 108.758 & 314.228 & 19.588 \\
\hline $\mathrm{Si}_{3} \mathrm{H}_{7} \mathrm{n}-\mathrm{SiH}_{3}-\mathrm{SiH}_{2}-\mathrm{SiH}_{2^{\star}}$ & 91.31208 & 262.379 & 280.452 & \pm 8 . & 114.942 & 354.048 & 21.217 \\
\hline $\mathrm{Si}_{3} \mathrm{H}_{7}+\mathrm{n}-\mathrm{SiH}_{3}-\mathrm{SiH}_{2}-\mathrm{SiH}_{2^{*}+}$ & 91.31153 & 965.767 & 996.160 & \pm 8 . & 116.509 & 347.994 & 21.336 \\
\hline $\mathrm{Si}_{3} \mathrm{H}_{7^{-}} \mathrm{n}-\mathrm{SiH}_{3}-\mathrm{SiH}_{2}-\mathrm{SiH}_{2^{*}}$ & 91.31263 & 56.170 & 79.445 & \pm 8 . & 113.947 & 346.165 & 20.944 \\
\hline $\mathrm{Si}_{3} \mathrm{H}_{7} \mathrm{i}-\mathrm{SiH}_{3}-\mathrm{SiH}_{*}-\mathrm{SiH}_{3}$ & 91.31208 & 251.718 & 269.829 & \pm 8 & 113.162 & 339.966 & 21.188 \\
\hline $\begin{array}{l}\mathrm{Si}_{3} \mathrm{H}_{7}+\mathrm{i}-\mathrm{SiH}_{3}-\mathrm{SiH}_{*}-\mathrm{SiH}_{3}+ \\
\text { cation }\end{array}$ & 91.31153 & 977.584 & 987.432 & \pm 8 & 115.382 & 344.968 & 22.331 \\
\hline $\mathrm{Si}_{3} \mathrm{H}_{7^{-}}-\mathrm{i}-\mathrm{SiH}_{3}-\mathrm{SiH}_{*}-\mathrm{SiH}_{3^{-}}$anion & 91.31263 & 28.806 & 52.471 & \pm 8 & 110.578 & 334.645 & 21.152 \\
\hline $\mathrm{Si}_{3} \mathrm{H}_{8}$ Trisilane & 92.32002 & 109.228 & 131.052 & \pm 8 . & 112.552 & 343.103 & 21.700 \\
\hline $\mathrm{Si}_{3} \mathrm{H}_{8}^{-}$Trisilane anion & 92.32057 & 122.122 & 147.101 & \pm 8 . & 123.630 & 346.629 & 23.036 \\
\hline $\mathrm{Si}_{4} \mathrm{H}_{7}$ Cyclotetrasilanyl & 119.39758 & 339.182 & 358.382 & \pm 12 . & 132.552 & 360.528 & 23.309 \\
\hline $\begin{array}{l}\mathrm{Si}_{4} \mathrm{H}_{7}^{+} \text {Cyclotetrasilanyl radical } \\
\text { cation }\end{array}$ & 119.39703 & 1026.227 & 1038.433 & \pm 12 . & 134.837 & 350.763 & 23.408 \\
\hline $\begin{array}{l}\mathrm{Si}_{4} \mathrm{H}_{7}^{-} \text {Cyclotetrasilanyl radical } \\
\text { anion }\end{array}$ & 119.39813 & 108.800 & 133.735 & \pm 12 & 131.810 & 351.163 & 23.105 \\
\hline $\mathrm{Si}_{4} \mathrm{H}_{8}$ Cyclotetrasilane & 120.40552 & 201.058 & 224.213 & \pm 12 & 137.843 & 342.156 & 23.587 \\
\hline $\mathrm{Si}_{4} \mathrm{H}_{8}^{+}$Cyclotetrasilane cation & 120.40497 & 1062.080 & 1075.116 & \pm 12 & 147.644 & 385.233 & 26.790 \\
\hline $\mathrm{Si}_{4} \mathrm{H}_{9} \mathrm{SiH}_{3}-\mathrm{SiH}_{2}-\mathrm{SiH}_{2}-\mathrm{SiH}_{2}{ }^{*}$ & 121.41346 & 293.750 & 317.669 & \pm 12 . & 149.814 & 409.481 & 27.658 \\
\hline $\mathrm{Si}_{4} \mathrm{H}_{9}+\mathrm{SiH}_{3}-\mathrm{SiH}_{2}-\mathrm{SiH}_{2}-\mathrm{SiH}_{2}+$ & 121.41291 & 939.986 & 958.090 & \pm 12 . & 146.722 & 380.952 & 25.276 \\
\hline $\mathrm{Si}_{4} \mathrm{H}_{9^{-}} \mathrm{SiH}_{3^{-}} \mathrm{SiH}_{2^{-}} \mathrm{SiH}_{2^{-}} \mathrm{SiH}_{2^{-}}$ & 121.41401 & 77.123 & 105.169 & \pm 12 . & 149.771 & 394.291 & 27.658 \\
\hline $\mathrm{Si}_{4} \mathrm{H}_{9} \quad \mathrm{SiH}_{3}-\mathrm{SiH}^{*}-\mathrm{SiH}_{2}-\mathrm{SiH}_{3}$ & 121.41346 & 285.869 & 309.074 & \pm 12 . & 151.369 & 405.267 & 27.761 \\
\hline $\mathrm{Si}_{4} \mathrm{H}_{9}+\mathrm{SiH}_{3}-\mathrm{SiH}^{*}-\mathrm{SiH}_{2}-\mathrm{SiH}_{3}+$ & 121.41291 & 984.922 & 1006.100 & \pm 12 & 147.899 & 399.839 & 28.157 \\
\hline $\mathrm{Si}_{4} \mathrm{H}_{9^{-}} \mathrm{SiH}_{3}-\mathrm{SiH}^{*}-\mathrm{SiH}_{2}-\mathrm{SiH}_{3^{-}}$ & 121.41401 & 47.910 & 76.253 & \pm 12 & 148.389 & 386.626 & 27.427 \\
\hline
\end{tabular}




\begin{tabular}{|c|c|c|c|c|c|c|c|}
\hline Compounds & $\begin{array}{r}\text { Mol. Wgt. } \\
\text { g/mol }\end{array}$ & $\begin{array}{r}\Delta_{\mathrm{f}} H_{298} \\
\mathrm{~kJ} / \mathrm{mol}\end{array}$ & $\begin{array}{r}\Delta_{\mathrm{f}} H_{0} \\
\mathrm{~kJ} / \mathrm{mol}\end{array}$ & $\begin{array}{l} \pm \mathrm{kJ} / \\
\mathrm{mol}\end{array}$ & $\begin{array}{l}C_{p 298} \\
\mathrm{~J} /(\mathrm{mol} \\
\mathrm{K})\end{array}$ & $\begin{array}{l}\mathrm{S}_{298} \\
\mathrm{~J} /(\mathrm{mol} \mathrm{K})\end{array}$ & $\begin{array}{l}\mathrm{H}_{298}-\mathrm{H}_{0} \\
\mathrm{~kJ} / \mathrm{mol}\end{array}$ \\
\hline $\mathrm{Si}_{4} \mathrm{H}_{9} \quad\left(\mathrm{SiH}_{3}\right)_{2}-\mathrm{SiH}-\mathrm{SiH}_{2}{ }^{*}$ & 121.41346 & 287.550 & 310.681 & \pm 12 . & 153.868 & 403.944 & 27.845 \\
\hline $\mathrm{Si}_{4} \mathrm{H}_{9}+\left(\mathrm{SiH}_{3}\right)_{2}-\mathrm{SiH}-\mathrm{SiH}_{2}{ }^{*}+$ & 121.41291 & 993.951 & 1008.415 & \pm 12 . & 151.507 & 404.473 & 28.292 \\
\hline $\mathrm{Si}_{4} \mathrm{H}_{9^{-}} \quad\left(\mathrm{SiH}_{3}\right)_{2}-\mathrm{SiH}-\mathrm{SiH}_{2}{ }^{*}-$ & 121.41401 & 66.328 & 93.914 & \pm 12 . & 153.044 & 397.181 & 27.769 \\
\hline $\mathrm{Si}_{4} \mathrm{H}_{9} \quad\left(\mathrm{SiH}_{3}\right)_{3} \mathrm{Si}^{*}$ & 121.41346 & 270.596 & 293.485 & \pm 12 . & 148.452 & 398.748 & 28.087 \\
\hline $\mathrm{Si}_{4} \mathrm{H}_{9^{-}}\left(\mathrm{SiH}_{3}\right)_{3} \mathrm{Si}^{*}-$ anion & 121.41401 & 17.853 & 46.024 & \pm 12 . & 150.442 & 381.591 & 27.264 \\
\hline $\mathrm{Si}_{4} \mathrm{H}_{10} \mathrm{n}$-Tetrasilane & 122.42140 & 142.863 & 170.592 & \pm 12 . & 152.455 & 407.440 & 27.482 \\
\hline $\mathrm{Si}_{4} \mathrm{H}_{10}{ }^{-} \mathrm{n}$-Tetrasilane anion & 122.42195 & 128.330 & 159.870 & \pm 12 . & 159.029 & 430.902 & 29.868 \\
\hline $\mathrm{Si}_{5} \mathrm{H}_{9}$ Cyclopentasilanyl radical & 149.49896 & 327.406 & 352.193 & \pm 15 . & 168.977 & 414.872 & 29.407 \\
\hline $\mathrm{Si}_{5} \mathrm{H}_{9}{ }^{+}$Cyclopentasilanyl cation & 149.49841 & 1027.423 & 1044.105 & \pm 15 & 172.120 & 421.981 & 30.445 \\
\hline $\mathrm{Si}_{5} \mathrm{H}_{9}{ }^{-}$Cyclopentasilanyl anion & 149.49951 & 79.813 & 109.943 & \pm 15 & 168.489 & 408.458 & 29.396 \\
\hline $\mathrm{Si}_{5} \mathrm{H}_{10}$ Cyclopentasilane & 150.50690 & 189.397 & 218.051 & \pm 15 . & 173.967 & 401.697 & 29.774 \\
\hline $\begin{array}{l}\mathrm{Si}_{5} \mathrm{H}_{10}{ }^{+} \text {Cyclopentasilane } \\
\text { cation }\end{array}$ & 150.50635 & 1058.569 & 1076.882 & \pm 15 & 185.851 & 430.374 & 32.990 \\
\hline $\mathrm{Si}_{5} \mathrm{H}_{12} \mathrm{n}$-Pentasilane & 152.52278 & 177.37 & 210.79 & \pm 15 . & 178.296 & 488.638 & 33.477 \\
\hline $\mathrm{Si}_{5} \mathrm{H}_{12}{ }^{-} \mathrm{n}$-Pentasilane anion & 152.52333 & 144.50 & 181.94 & \pm 15 . & 184.268 & 508.548 & 35.649 \\
\hline $\mathrm{Si}_{6} \mathrm{H}_{11}$ Cyclohexasilanyl & 179.60034 & 351.611 & 381.832 & \pm 20 . & 205.391 & 465.188 & 35.658 \\
\hline $\mathrm{Si}_{6} \mathrm{H}_{11}{ }^{+}$Cyclohexasilanyl cation & 179.59979 & 1039.444 & 1061.152 & \pm 20 . & 208.642 & 468.661 & 36.538 \\
\hline $\mathrm{Si}_{6} \mathrm{H}_{11}{ }^{-}$Cyclohexasilanyl anion & 179.60089 & 99.118 & 134.541 & \pm 20 . & 204.763 & 457.281 & 35.598 \\
\hline $\mathrm{Si}_{6} \mathrm{H}_{12}$ Cyclohexasilane & 180.60828 & 212.476 & 246.543 & \pm 20 . & 210.583 & 447.199 & 36.045 \\
\hline $\mathrm{Si}_{6} \mathrm{H}_{12}{ }^{+}$Cyclohexasilane cation & 180.60773 & 1074.209 & 1098.128 & \pm 20 & 222.369 & 474.835 & 38.858 \\
\hline $\mathrm{Si}_{6} \mathrm{H}_{12}{ }^{-}$Cyclohexasilane anion & 180.60883 & 204.191 & 241.492 & \pm 20 . & 216.896 & 465.731 & 37.900 \\
\hline
\end{tabular}


Table 2 Thermochemical properties of Organic Si containing compounds. Molecular Weights, $\Delta_{\mathrm{f}} H_{298}, \Delta_{\mathrm{f}} H_{0}, C_{p 298}, S_{298}, H_{298}-H_{0}$. The standard state corresponds to a pressure of 1 bar and 298.15K.

\begin{tabular}{|c|c|c|c|c|c|c|c|}
\hline Compound & $\begin{array}{l}\text { Mol. Wgt. } \\
\text { g/mol }\end{array}$ & $\begin{array}{l}\Delta_{\mathrm{f}} H_{298} \\
\mathrm{~kJ} / \mathrm{mol}\end{array}$ & $\begin{array}{l}\Delta_{\mathrm{f}} H_{0} \\
\mathrm{~kJ} / \mathrm{mol}\end{array}$ & \begin{tabular}{|l|} 
\pm \\
$\mathrm{kJ} / \mathrm{mo}$ \\
$\mathrm{I}$
\end{tabular} & \begin{tabular}{|l|}
$C_{p 298}$ \\
$\mathrm{~J} /(\mathrm{mol}$ \\
$\mathrm{K})$
\end{tabular} & \begin{tabular}{|l}
$\mathbf{S}_{298}$ \\
$\mathrm{~J} /(\mathrm{mol}$ \\
$\mathrm{K})$
\end{tabular} & $\begin{array}{l}\mathrm{H}_{298}-\mathrm{H}_{0} \\
\mathrm{~kJ} / \mathrm{mol}\end{array}$ \\
\hline $\mathrm{CH}_{2} \mathrm{Si} \mathrm{HSi} \equiv \mathrm{CH}$ & 42.11208 & 452.424 & 453.661 & \pm 8 & 47.841 & 241.991 & 11.503 \\
\hline $\mathrm{CH}_{2} \mathrm{Si}^{-} \mathrm{HSi}=\mathrm{CH}$ anion & 42.11263 & 338.644 & 346.284 & \pm 8 & 47.098 & 248.026 & 11.170 \\
\hline $\mathrm{CH}_{4} \mathrm{Si} \quad \mathrm{H}_{2} \mathrm{C}=\mathrm{SiH}_{2}$ & 44.12796 & 187.276 & 196.311 & \pm 8 . & 56.872 & 245.568 & 12.168 \\
\hline $\mathrm{CH}_{4} \mathrm{Si}^{+} \quad \mathrm{H}_{2} \mathrm{C}=\mathrm{SiH}_{2}$ & 44.12741 & 1051.435 & 1053.766 & \pm 8 . & 58.636 & 253.837 & 12.464 \\
\hline $\mathrm{CH}_{4} \mathrm{Si}^{-} \mathrm{H}_{2} \mathrm{C}=\mathrm{SiH}_{2}$ anion & 44.12851 & 177.426 & 191.439 & \pm 8 & 62.287 & 264.645 & 13.165 \\
\hline $\mathrm{CH}_{5} \mathrm{Si}^{*} \mathrm{CH}_{3}-\mathrm{SiH}_{2}{ }^{*}$ radical & 45.13590 & 141.879 & 154.470 & \pm 8 . & 61.598 & 258.522 & 12.851 \\
\hline $\mathrm{CH}_{5} \mathrm{Si}^{*+} \mathrm{CH}_{3}-\mathrm{SiH}_{2}{ }^{*+}$ cation & 45.13535 & 864.938 & 869.895 & \pm 8 . & 58.975 & 263.859 & 13.358 \\
\hline $\mathrm{CH}_{5} \mathrm{Si}^{*^{-}} \mathrm{CH}_{3}-\mathrm{SiH}_{2}{ }^{*^{-}}$anion & 45.13645 & 22.434 & 40.694 & \pm 8 . & 61.340 & 256.661 & 12.773 \\
\hline $\mathrm{CH}_{3} \mathrm{SiH}_{3} \quad \mathrm{CH}_{3} \mathrm{SiH}_{3}$ Methylsilane & 46.14384 & -27.420 & -11.579 & \pm 8 . & 66.009 & 267.332 & 13.827 \\
\hline $\begin{array}{l}\mathrm{CH}_{3} \mathrm{SiH}_{3}^{+} \mathrm{CH}_{3} \mathrm{SiH}_{3}^{+} \text {Methylsilane } \\
\text { cation }\end{array}$ & 46.14329 & 1001.110 & 1007.766 & \pm 8 & 81.219 & 285.168 & 16.670 \\
\hline $\mathrm{CH}_{6} \mathrm{Si}_{2} \mathrm{CH}_{3} \mathrm{SiH}_{2} \mathrm{SiH}$ & 74.22934 & 247.902 & 262.599 & \pm 8 . & 93.052 & 313.855 & 18.196 \\
\hline $\mathrm{CH}_{6} \mathrm{Si}_{2}{ }^{+} \mathrm{CH}_{3} \mathrm{SiH}_{2} \mathrm{SiH}$ cation & 74.22879 & 1038.277 & 1045.198 & \pm 8 . & 95.143 & 343.868 & 18.756 \\
\hline $\mathrm{CH}_{6} \mathrm{Si}_{2}^{-} \mathrm{CH}_{3} \mathrm{SiH}_{2} \mathrm{SiH}$ anion & 74.22989 & 82.365 & 108.692 & \pm 8 & 92.630 & 338.515 & 18.053 \\
\hline $\mathrm{C}_{2} \mathrm{H}_{4} \mathrm{Si} \mathrm{CH}_{2}=\mathrm{CH}-\mathrm{SiH}$ & 56.13866 & 307.432 & 315.538 & \pm 8. & 65.371 & 278.892 & 14.155 \\
\hline $\mathrm{C}_{2} \mathrm{H}_{4} \mathrm{Si}^{+} \mathrm{CH}_{2}=\mathrm{CH}-\mathrm{SiH}$ cation & 56.13111 & 1122.630 & 1124.454 & \pm 8 . & 65.910 & 276.057 & 13.997 \\
\hline $\mathrm{C}_{2} \mathrm{H}_{4} \mathrm{Si}^{-} \mathrm{CH}_{2}=\mathrm{CH}-\mathrm{SiH}$ anion & 56.13921 & 200.882 & 214.961 & \pm 8 & 67.638 & 276.355 & 14.121 \\
\hline $\mathrm{C}_{2} \mathrm{H}_{6} \mathrm{Si} \mathrm{CH} \mathrm{CH}_{2}=\mathrm{CH}-\mathrm{SiH}_{3}$ & 58.15454 & 90.174 & 106.267 & \pm 8 . & 75.903 & 280.937 & 14.636 \\
\hline $\mathrm{C}_{2} \mathrm{H}_{6} \mathrm{Si}^{+} \mathrm{CH}_{2}=\mathrm{CH}-\mathrm{SiH}_{3}$ cation & 58.15399 & 1062.586 & 1070.361 & \pm 8 . & 80.135 & 300.154 & 16.145 \\
\hline $\mathrm{C}_{2} \mathrm{H}_{6} \mathrm{Si}^{-} \mathrm{CH}_{2}=\mathrm{CH}-\mathrm{SiH}_{3}$ anion & 58.15509 & 165.192 & 183.899 & \pm 8 & 89.718 & 303.118 & 17.357 \\
\hline $\mathrm{C}_{2} \mathrm{H}_{6} \mathrm{Si} \mathrm{CH}_{2}=\mathrm{SiH}-\mathrm{CH}_{3}$ & 58.15454 & 125.817 & 140.865 & \pm 8 . & 82.212 & 287.045 & 15.681 \\
\hline $\mathrm{C}_{2} \mathrm{H}_{6} \mathrm{Si}^{+} \mathrm{CH}_{2}=\mathrm{SiH}-\mathrm{CH}_{3}$ cation & 58.15399 & 938.099 & 945.379 & \pm 8. & 81.677 & 302.032 & 16.633 \\
\hline $\mathrm{C}_{2} \mathrm{H}_{6} \mathrm{Si}^{-} \quad \mathrm{CH}_{2}=\mathrm{SiH}-\mathrm{CH}_{3}$ anion & 58.15509 & 131.628 & 151.072 & \pm 8 & 87.328 & 299.695 & 16.631 \\
\hline $\mathrm{C}_{2} \mathrm{H}_{8} \mathrm{Si} \mathrm{H}_{3} \mathrm{C}-\mathrm{SiH}_{2} \mathrm{CH}_{3}$ & 60.17042 & -88.190 & -65.677 & \pm 8 . & 90.149 & 289.540 & 16.683 \\
\hline $\mathrm{C}_{2} \mathrm{H}_{8} \mathrm{Si}^{+} \mathrm{CH}_{3} \mathrm{SiH}_{2} \mathrm{CH}_{3}^{+}$cation & 60.16987 & 893.340 & 906.884 & \pm 8 & 104.302 & 313.942 & 19.455 \\
\hline $\mathrm{C}_{2} \mathrm{H}_{8} \mathrm{Si}^{-} \mathrm{CH}_{3} \mathrm{SiH}_{2} \mathrm{CH}_{3}^{-}$anion & 60.17097 & 68.684 & 96.104 & \pm 8 & 98.317 & 303.243 & 17.974 \\
\hline $\mathrm{C}_{2} \mathrm{H}_{8} \mathrm{Si} \mathrm{C}_{2} \mathrm{H}_{5} \mathrm{SiH}_{3}$ & 60.17042 & -36.116 & -12.942 & \pm 8 . & 85.192 & 291.590 & 16.023 \\
\hline $\mathrm{C}_{2} \mathrm{H}_{8} \mathrm{Si}^{+} \mathrm{C}_{2} \mathrm{H}_{5} \mathrm{SiH}_{3}^{+}$cation & 60.16987 & 929.961 & 943.743 & \pm 8 & 96.348 & 307.231 & 17.853 \\
\hline $\mathrm{C}_{3} \mathrm{H}_{9} \mathrm{Si} \mathrm{Si}\left(\mathrm{CH}_{3}\right)_{3}$ radical & 73.18906 & 24.175 & 48.091 & \pm 8. & 112.449 & 324.106 & 20.568 \\
\hline $\mathrm{C}_{3} \mathrm{H}_{10} \mathrm{Si}\left(\mathrm{CH}_{3}\right)_{3} \mathrm{SiH}$ & 74.1970 & -153.193 & -125.366 & \pm 8 . & 117.339 & 319.711 & 20.891 \\
\hline $\mathrm{C}_{4} \mathrm{H}_{12} \mathrm{Si} \mathrm{Si}\left(\mathrm{CH}_{3}\right)_{4}$ & 88.22358 & -219.338 & -186.489 & \pm 8 . & 145.448 & 344.106 & 25.391 \\
\hline $\mathrm{C}_{4} \mathrm{H}_{12} \mathrm{Si}^{+} \mathrm{Si}\left(\mathrm{CH}_{3}\right)_{4}^{+}$cation & 88.22303 & 706.536 & 728.016 & \pm 8 . & 156.214 & 361.645 & 27.654 \\
\hline $\mathrm{C}_{4} \mathrm{H}_{12} \mathrm{Si}\left(\mathrm{C}_{2} \mathrm{H}_{5}\right)_{2} \mathrm{SiH}_{2}$ & 88.22358 & -106.002 & -72.329 & \pm 8 . & 129.567 & 372.008 & 24.567 \\
\hline $\mathrm{C}_{4} \mathrm{H}_{12} \mathrm{Si}^{+}\left(\mathrm{C}_{2} \mathrm{H}_{5}\right)_{2} \mathrm{SiH}_{2}^{+}$cation & 88.22303 & 821.349 & 845.565 & \pm 8 & 140.733 & 386.178 & 26.787 \\
\hline
\end{tabular}




\begin{tabular}{|c|c|c|c|c|c|c|c|}
\hline Compound & $\begin{array}{l}\text { Mol. Wgt. } \\
\text { g/mol }\end{array}$ & $\begin{array}{l}\Delta_{\mathrm{f}} H_{298} \\
\mathrm{~kJ} / \mathrm{mol}\end{array}$ & \begin{tabular}{|l}
$\Delta_{\mathrm{f}} H_{0}$ \\
$\mathrm{~kJ} / \mathrm{mol}$
\end{tabular} & \begin{tabular}{|l|} 
\pm \\
$\mathrm{kJ} / \mathrm{mo}$ \\
$\mathrm{I}$
\end{tabular} & \begin{tabular}{|l|}
$C_{p 298}$ \\
$\mathrm{~J} /(\mathrm{mol}$ \\
$\mathrm{K})$
\end{tabular} & \begin{tabular}{|l|}
$\mathrm{S}_{298}$ \\
$\mathrm{~J} /(\mathrm{mol}$ \\
$\mathrm{K})$
\end{tabular} & $\begin{array}{l}\mathrm{H}_{298}-\mathrm{H}_{0} \\
\mathrm{~kJ} / \mathrm{mol}\end{array}$ \\
\hline $\mathrm{C}_{6} \mathrm{H}_{8} \mathrm{Si} \mathrm{C}_{6} \mathrm{H}_{5}-\mathrm{SiH}_{3}$ Phenylsilane & 108.21322 & 123.056 & 146.625 & \pm 8 . & 114.369 & 337.995 & 19.842 \\
\hline $\begin{array}{l}\mathrm{C}_{6} \mathrm{H}_{8} \mathrm{Si}^{-} \mathrm{C}_{6} \mathrm{H}_{5}-\mathrm{SiH}_{3}-\text { Phenylsilane } \\
\text { anion }\end{array}$ & 108.21377 & 164.700 & 191.615 & \pm 8 & 128.950 & 349.744 & 22.002 \\
\hline
\end{tabular}

